\title{
Constructive Conflict Talk in Classrooms: Divergent Approaches to Addressing Divergent Perspectives
}

\author{
Kathy Bickmore \\ University of Toronto \\ Christina Parker \\ Ryerson University
}

This is an Accepted Manuscript of an article published by Taylor \& Francis:

Bickmore, Kathy \& Parker, Christina (2014). Constructive Conflict Talk in Classrooms:

Divergent Approaches to Addressing Divergent Perspectives. Theory and Research in

Social Education 42(4), 291-335. doi: 10.1080/00933104.2014.901199

\begin{abstract}
Dialogue about social and political conflicts is a key element of democratic citizenship education that is frequently advocated in scholarship but rarely fully implemented, especially in classrooms populated by ethnically and economically heterogeneous students. Qualitative case studies describe the contrasting ways two primary and two middle grade teachers in urban Canadian public schools infused conflict dialogue pedagogies into their implemented curricula. These lessons, introducing conflict communication skills and/or content knowledge embodying conflicting viewpoints as learning opportunities, actively engaged a wide range of students. At the same time, even these purposively selected teachers did not often facilitate sustained, inclusive, critical and imaginative exchange or deliberation about heartfelt disagreements, or probe the diversity and equity questions surrounding these issues. The case studies illustrate a democratic education dilemma: Even in the classrooms of skilled and committed teachers, opportunities for recognition of contrasting perspectives and discussion of social conflicts may not necessarily develop into sustained democratic dialogue, nor interrupt prevailing patterns of disengagement and inequity.
\end{abstract}

Keywords: peace-building, classroom discussion, K-12 schools, curriculum studies, diversity, conflictual issues, democratic education.

Democratic citizenship education scholars frequently advocate dialogue and deliberation pedagogies that address diverse perspectives on conflictual questions (e.g., Davies, 2005; Hahn, 2010; Hess \& Avery, 2008; W. Parker, 2006; Sears \& Hughes, 2006). Contentious social and political problems, and interpersonal disputes, can be addressed in classrooms in ways that offer — or deny — equitable, constructive, and guided opportunities to learn. However, typical curriculum implemented in many US, Canadian, and other public school classrooms, especially 
among non-affluent and ethnically heterogeneous students, tends to avoid or curtail such democratic dialogue (Hughes, Print, \& Sears, 2010; Kahne \& Middaugh, 2008).

The classroom case studies in this article are drawn from a larger project examining contrasting peace-building education initiatives. Canadian public school teachers received professional development support to implement and facilitate dialogue about various kinds of conflicts, in the context of their regular work in curriculum and classroom management. The goal was to learn how such pedagogies might become feasible, high quality, and accessible to diverse students in public classroom settings. Even in these purposively-sampled classrooms linked to professional development on dialogic conflict education, relatively few of the lessons we observed addressed controversial or sensitive issues in ways that invited sustained, passionate, and inclusive exchange among disagreeing viewpoints. Instead, the teachers tended to engage students in calmer, more distanced learning activities, evidently intended as preparation for 'hotter' conflict dialogue that might occur later, outside these classrooms. Through analysis of classroom observations and interviews, we examine contrasting pedagogical strategies teachers used to prepare and/or facilitate student dialogue on challenging conflict issues, what kinds of conflicts they addressed, and the ways each teacher facilitated engagement of diverse students in these opportunities to develop as democratic citizens.

\section{'Democratic' Conflict Dialogue in Classroom Curriculum?}

Democratic participation and governance rely upon conversation, negotiation, and decision-making about conflict in the context of social difference and inequity. Peace-building refers to comprehensive systems of long-term democratic transformation to overcome injustice and nurture healthy social relationships - to redress the causes of direct and systemic violence, as well as to constructively handle conflicts after they become visible. Paulo Freire (1970) and other critical educational scholars argue that engaging heterogeneous and marginalized people in "problem-posing education" and "praxis"_ critical dialogue about social conflicts, and on-going cycles of reflection and action on those problems - facilitate democratization. In contrast, traditional top-down delivery of ostensibly-uncontestable knowledge, masking or denying the extent of social conflict, implicitly reinforces dominant-system beliefs and practices (Apple, 1979). Contemporary policies of curriculum standardization and high-stakes testing marginalize dissent and diversity, which advantages those at the top of existing hierarchies. Interrupting the status quo by inviting confrontation and constructively critical talk about conflict is essential to 
any complex, living democracy (Davies, 2004) and to building just, sustainable peace (Curle, Freire, \& Galtung, 1974).

By conflict dialogue, we mean various kinds of conversation processes in which participants talk together about differing and opposing perspectives on social, political, cultural, and/or interpersonal issues (Schirch \& Campt, 2007). Dialogue may emphasize learning goals, as in issues discussion seminars and talking circles, and/or decision-making goals, as in deliberation, conflict resolution, and restorative justice (W. Parker, 2010; Pranis, Stuart, \& Wedge, 2003). Dialogue processes, unlike debate, focus on cooperating to develop mutual understanding rather than on competing or winning.

Contrasting ideologies, perspectives, and problems - conflicts - underlie any school subject matter, and may be brought into the light, probed and discussed in classroom pedagogy. Conflict dialogue, infused into curriculum, may focus on a range of subject-matter-such as bias and intolerance, questions of global responsibility, competing interests of historical actors, or the reliability of statistical representations of policy problems - not only 'controversial' political issues (Avery, Johnson, \& Johnson, 1999; Crocco \& Cramer, 2005; Frankenstein, 1987; Murphy, 2010; Sills-Briegel \& Camp, 2000; Stevahn, 2004). For instance, David and Roger Johnson (2009) propose a pedagogy they call Structured Academic Controversy, which they describe as "a procedure for learning, not for addressing controversial issues or controversial subject matter" (p. 39). Like Settlage and Sabik (1996) and others, they argue that addressing "intellectual" conflicts makes subject matter engaging:

Conflict is to student learning what the internal combustion engine is to the automobile. The internal combustion engine ignites the fuel and the air with a spark to create the energy for movement and acceleration. Just as the fuel and the air are inert without the spark, so, ideas in the classroom are inert without the spark of intellectual conflict. Intellectual conflict is the spark that energizes students to seek out new information and study harder and longer. (Johnson \& Johnson, 2009, p. 37)

According to an accumulating international body of research, students who report they have had significant opportunities in school to participate in thoughtful discussion of conflictual social issues in open, inclusive classroom climates tend to exhibit (on the same survey assessments) democratically-relevant understandings, skills and dispositions - such as openness to alternative points of view, tolerance for dissent, sensitivity to inequity, critical thinking skills, 
deepened understanding of subject-matter discussed, inclinations to participate in democratic processes, and sense of political efficacy (Hahn, 1998, 2010; Hess \& Avery, 2008; Schulz, Ainley, Fraillon, Kerr, \& Losito, 2009; Torney-Purta, Lehmann, Oswald, \& Schultz, 2001). Even when their teachers prefer to avoid addressing conflictual issues, students of all ages often express interest in discussing them, and describe the rare occasions when conflicts are discussed as their most meaningful classroom experiences (Simon, 2001; Yamashita, 2006).

Many teachers report that they would like to (or do) teach about and discuss conflicts, but feel constrained by fear of backlash from parent communities, mandated curriculum and assessment demands (Parker \& Bickmore, 2012). Or, they believe that their students would be too immature or undisciplined to handle such engaging pedagogies (Wilson, Haas, Laughlin, \& Sunal, 2002). Some teachers, perhaps especially in elementary contexts, tend to emphasize safe and "caring" relationships in ways that avoid educative "dissonance" (Houser, 1996). Teachers evidently choose whether to raise challenging questions based upon how secure they feel about their classroom control, in ways possibly complicated by their own race and class prejudices (also Larson \& Parker, 1996). Almost three-fourths of the 67 Oklahoma and Indiana high school social studies teachers surveyed by Byford, Lennon, and Russell (2009) reported that they were positively inclined toward the teaching of conflictual issues, and an almost equal proportion believed that students need to be taught how to deal with conflict. However, $60 \%$ of these teachers also indicated that they felt compelled to protect themselves by avoiding topics that were controversial within their communities.

Teachers also frequently feel constrained by administrative pressures around narrow standardized tests and mandates to cover vast amounts of content in breadth as opposed to in depth (Pace, 2011), difficulty accessing resources that show multiple sides of conflictual issues (Dean \& Joldoshalieva, 2007; Finley, 2003), and short, rigid instructional periods (McLaughlin, Pfeifer, Swanson-Owens, \& Yee, 1986; W. Parker, 2003). Many teachers report that they were not exposed to conflict dialogue learning as students, and thus lack models of what such teaching might look like (Bickmore, 2008; Hess, 2009). Teachers also express concern over their own content knowledge and pedagogical skills (Claire \& Holden, 2007; Hess \& Avery, 2008). Further, there is often at best minimal support for professional development in areas related to teaching with conflict dialogue (Bickmore, 2005; McLaughlin, et al., 1986; Torney-Purta, Richardson, \& Barber, 2005). Thus, although thoughtful classroom dialogue about conflictual 
matters has potential ramifications for democracy and peacebuilding, unfortunately it is implemented infrequently and constrained by various school system factors.

\section{Conflict Dialogue Pedagogies Intersect with Student Diversity and Equity}

Sustained implementation of conflict dialogue pedagogies is especially rare in classrooms serving diverse and/or marginalized students (Hess \& Avery, 2008). For example, in Dull and Murrow's observations of 26 urban, suburban, and rural classrooms (2008), by far the most prevalent teacher questioning patterns invited short-answer review of informational content (recitation), rather than "sustained interpretive" or values (higher-order and open-ended) questioning that could have invited constructive conflictual dialogue (p. 392). Further, they found these lower-order questioning patterns (ignoring or silencing conflicting perspectives) were used disproportionately more in lower socio-economic status and ethnically heterogeneous classrooms. Thus the democratic peacebuilding learning opportunities represented by conflict dialogue pedagogies seem to be generally less available to the young people who are already most often marginalized as citizens.

School opportunities can help to overcome inequalities in democratic access. The International Civics and Citizenship Study (Schulz, et al., 2009) reports that, in most of the 38 participating countries, students on average had more opportunities to engage in discussions of civic and political issues at school than at home. Results from a survey of over 4000 nonaffluent visible minority students in Chicago public schools (Kahne \& Sporte, 2008) suggest that conflict discussion and other civic learning opportunities at school may be especially important for alleviating marginalization of those students who have fewer civic learning opportunities outside of school (see also Kahne \& Middaugh, 2008). Other research affirms the utility of discussion-based pedagogies for facilitating diverse students' academic success and helping to overcome academic inequalities (Applebee, Langer, Nystrand, \& Gamoran, 2003). However, the above research makes clear that such opportunities for thoughtful dialogue, interconnected with academic subject matter, are unfortunately rare in public schools.

Like any form of citizenship education, conflict dialogue pedagogy inevitably takes place in the context of diverse, fluctuating social identities and unequal social power, within and surrounding the classroom dynamic (C. Parker, 2012). Scholars disagree about the extent to which it is possible or desirable for teachers to take unbiased stances in relation to the conflict dialogue they facilitate (Barton \& McCully, 2007; Fine, 1993; Hess \& Avery, 2008; McKenzie, 
2006; Obenchain, Pennington, \& Orr, 2010). Lessons may be taught from a distinct point of view (for instance, supporting human rights), and yet address conflicting viewpoints about why injustices persist, or about participants' responsibilities in perpetuating or resisting them (Avery, Sullivan, \& Wood, 1997; Boler, 1997; Schweber, 2006).

Students' learning experiences and peer status are influenced by their fluid and intersecting identities, subject positions in relation to social inequality, and community narratives about themselves and others (Epstein, 2000; Funk \& Said, 2004; Hollingworth, 2009; Kumashiro, 2000; Mátrai, 2002). Implicit messages about identities and politics are communicated through discourses and social interactions (Arnot \& Dillabough, 1999; Bixby \& Pace, 2005; Howard, 2004; Pace, 2005). At the same time, pedagogical choices such as welldefined active roles for diverse students in cooperative learning activities (Cohen, 2004) and critical analysis of dominant cultural knowledge, narratives and institutions (Ahonen, 2001; Freire, 1998) can help to alleviate such status inequalities. Interactions among students, between student(s) and teacher, and between students and subject-matter influence lived citizenship learning experiences in relation to social conflict (also Dei, 2000; Gordon, Holland, \& Lahelma, 2000; Ladson-Billings, 1995).

Education for democratic transformation requires "the unleashing of unpopular things" (Britzman, 1992, p. 151). At the same time, open conflict is likely riskiest for lower-status students: It is not easy to open 'safer' spaces for marginalized students to address identity-linked conflicts (e.g. King, 2009; Subedi, 2008). Debate processes, by emphasizing competition among ideas, seem to further marginalize lower-status and less confident students, compared with more cooperative, open and inclusive discussion processes that emphasize mutual understanding (Hemmings, 2000). Consequently, equitable conflict dialogue requires a sustained series of carefully-planned interactions to transform social relations, both contesting dominant narratives (content) and changing patterns of dialogic interaction (process) inside the educational context (Tawil \& Harley, 2004; Williams, 2004). Our research investigated the lived complexities of conflictual dialogic education in implemented curriculum and the practices that may have made such pedagogies feasible, constructive, educative, and equitable.

\section{Elements of Equitable Democratic Conflict Dialogue Pedagogies}

A too-often neglected element of conflict dialogue is preparation-developing norms and relationships for respectful nonviolent interaction, as well as participants' understanding of 
diverse stakeholders' perspectives and their roots in particular social contexts (Prutzman \& Johnson, 1997; Zembylas, Bekerman, McGlynn, \& Ferreira, 2009). People from dominant groups usually know less about the 'other' than the 'others' know about the mainstream (Anzaldúa, 1987), so allocating time to building mutual background knowledge and trust has ramifications for equity in conflict dialogue pedagogies. Opportunities for listening and individual reflection, to encounter alternatives and how they matter to others, to discern one's own point of view, and to link classroom knowledge to students' particular (diverse) beliefs and experience bases are also important (King, 2009; W. Parker, 2010; Schultz, 2009). Conflict resolution education (Bickmore, 2001, 2007, 2011a; Bickmore \& MacDonald, 2010; Harris, 2004; Jones, 2004; Skiba, 2000) and critical literacies (Espinosa, 2003; Finn, 1999; Luke, 2000) research also demonstrate the value of instruction and guided practice in skills and processes for talking about conflict. Thus students, as well as teachers in training, need what Parker and Hess (2001) call "teaching for discussion" (p. 273) to learn steps and alternate processes for discussing conflict and facilitating dialogic processes.

Classroom dialogue about conflict requires imagination and emotional engagement, not just rational cognition (e.g. Barton \& McCully, 2005; Case, 1999; Kohlmeier, 2006; Smith \& Fairman, 2005). The diverse perspectives of characters in fictional literature and poetry, as well as in historical narratives, provide opportunities to discern and discuss diverse frames of reference, wants and needs, and questions of justice (DeNicolo \& Franquiz, 2006; Fain, 2008; McCall, 2004; Wasson, Anderson, \& Suriani, 1999). Students' writing and improvisational drama about justice conflicts in their own lives also can fuel dialogic learning (Day, 2002; Finn, 1999; O'Toole \& Burton, 2005). Such opportunities for students to imagine (and perform) roles other than their own in conflicts - to distance themselves temporarily from their own identities - may create space and reduce risks for broader participation and representation of divergent points of view in classroom conversations.

Another key element of equitable conflict dialogue pedagogy is inclusive opportunities for all students to voice perspectives and to be heard (C. Parker, 2012). The Structured Academic Controversy procedure, mentioned above, accomplishes such inclusivity through a structured process in which students, working with a partner, engage in dialogues between two pairs who articulate opposing viewpoints (Avery, et al., 1999). Thus, each student has both peer support and small-group opportunities to speak and be heard. A different approach to sharing 
'air space' among many viewpoints and voices is derived from Aboriginal traditions in North America and New Zealand: restorative peacemaking circle dialogue processes may be used for proactive education and community-building in classrooms and for intensive problem solving after harmful incidents (Claassen \& Claassen, 2004; Pranis, 2005). The teachers profiled below participated in professional development workshops on one form of circle process, in which a facilitator asks a graduated series of questions to establish norms and engage hearts, minds, and contrasting voices in addressing a conflict, circulating a talking piece to give each participant an explicit opportunity to respond (or not) to each question. Morrison (2007), reviewed the results of early research on these and other school-based restorative peacemaking initiatives in Australia, England, the United States, and Canada, and concluded that:

The power of the [restorative justice dialogue] process comes from the engine of emotional engagement of the participants, in contrast to the suppression of participants' emotions in [mainstream, legal-type] determinations of guilt. (p. 85)

Thus conflict talk, whether for post-incident peacemaking or for pro-active democratic education, may build upon the power of emotion as well as reason, in ways that build upon (and are complicated by) diverse social experience and inequality.

Table 1 is derived from the above literature review and refined through our data analysis. It shows a typology of conflict dialogue pedagogy elements for democratic peace-building, which we employed to scaffold our analysis of specific, classroom-level descriptive case studies of differing dialogue-related classroom pedagogies and the ways diverse students responded to them. The typology includes overlapping categories of conflict dialogue or preparation activities. We enumerate characteristics of each, juxtaposed with other scholars' conceptualizations: Johnson and Johnson's (2009) typology of processes for conflict talk (individualistic efforts, concurrence seeking, debate, and constructive controversy), Larson and W. Parker's (1996) typology of classroom discussion (recitation, teacher-centered conversation, open-ended conversation, posing challenging questions, and application) and Dull and Murrow's (2008) typology of teacher questioning (information gathering, values questioning, and sustained interpretive dialogue). Each of these discussion typologies also includes the more prevalent individualistic efforts, recitation, and information gathering approaches that would not involve conflict dialogue. We extend Parker and Hess' (2001) notion of teaching 'for' discussion to foreground knowledge-building and process (norm and skill) elements for students. The 
typology is arranged from least to greatest potential for democratic peace-building engagement and agency.

Table 1. Elements of Conflict Dialogue Pedagogies for Peacebuilding Citizenship

Elements of Conflict Dialogue Characteristics and Sources
Pedagogies

\section{PREPARATION}

Teach 'about' conflicts: build Address conflicts as learning opportunities understanding of social problems \& alternate perspectives/challenges - "Teacher-centered conversation" (Larson \& Parker, 1996) or "information gathering" questions (Dull \& Murrow, 2008) may present \& acknowledge conflicting viewpoints \& concerns

Teach 'about' diversities: build understanding of social difference, unequal power, contrasting worldviews

Examine divergent experiences \& identities

- "Teacher-centered conversation" (Larson \& Parker, 1996) or "information gathering" questions (Dull \& Murrow, 2008) may include diverse experiences, identities \& social positions as factors in conflicts - Address "social-structural" (tangible interests \& [inter]dependence) and "psycho-cultural" (narratives, fears) causes of conflicts (Ross, 2007)

Guide constructive conflict Teach, scaffold \& encourage thinking, inquiry \& communication skills, norms, communication skills

\& relationships (cross-cutting Establish 'safe' \& 'open' space: cultivate respect, social ties) tolerance, open minds

- "Teach for discussion" (Parker \& Hess, 2001) extended to students/ classrooms

- "Conflict resolution education" (Jones, 2004; Harris 2004)

- "Restorative justice practices" (Morrison, 2007)

- Structure (\& train for) equitable groupwork roles \& cooperative tasks (Aronson, 2000; Cohen, 1994)

\begin{tabular}{ll}
\hline AGENCY \& ENGAGEMENT & \\
\hline Inviting students to 'locate & Invite affective, imaginative \& intellectual engagement \\
themselves in' conflicts & \& reflexivity \\
& • "Values questioning" (Dull \& Murrow, 2008) \\
- "Posing challenging questions" (Larson \& Parker, \\
1996) \\
• Private reflection, writing \& self-assessment \\
assignments, for students to identify their own \\
perspectives \& choices in conflicts \\
• Pair \& small group dialogue activities, for students to \\
articulate \& listen to each other's perspectives (e.g. \\
think-pair-share)
\end{tabular}




\begin{tabular}{|c|c|}
\hline $\begin{array}{l}\text { Inviting students to 'enter into' } \\
\text { conflict (publicly express } \\
\text { dissonant views) }\end{array}$ & $\begin{array}{l}\text { Invite democratic engagement, active empathy } \\
\text { (discerning \& engaging with others' perspectives), } \\
\text { equal opportunity \& voice (share power) } \\
\text { - "Application" (Larson \& Parker, 1996) } \\
\text { - Taking-a-stand task structures, for students to } \\
\text { physically demonstrate choices to the group by placing } \\
\text { themselves in relative locations, such as on an opinion } \\
\text { spectrum line or in corners representing alternative } \\
\text { courses of action) } \\
\text { - Perspective-taking 'in role' (articulating the } \\
\text { perspectives of characters in fictional, historical or } \\
\text { contemporary scenarios) } \\
\text { - Perspective-taking 'for oneself' (articulating one's } \\
\text { own viewpoint) } \\
\text { - Sharing: participants communicate \& exchange views } \\
\text { without direct peer response, as in a talking circle, or } \\
\text { responding ('vertically,' to teacher's questions (may } \\
\text { [not] be 'Concurrence seeking" -Johnson \& Johnson, } \\
\text { 2009) }\end{array}$ \\
\hline Conflict dialogue & $\begin{array}{l}\text { Facilitate 'horizontal' exchange \& mutual response } \\
\text { among students, equal opportunity \& voice } \\
\text { - May be guided by "Values questioning" \&/or } \\
\text { "Sustained interpretive questioning" (Dull \& Murrow, } \\
\text { 2008) or "Posing challenging questions" (Larson \& } \\
\text { Parker, 1996), but students address one another } \\
\text { - Debate (competitive) OR "Constructive controversy" } \\
\text { (Johnson \& Johnson, 2009), OR "Open-ended } \\
\text { conversations" (Larson \& Parker, 1996) }\end{array}$ \\
\hline $\begin{array}{l}\text { Collective decision making in } \\
\text { response to conflict }\end{array}$ & $\begin{array}{l}\text { Facilitate 'horizontal' exchange \& mutual response } \\
\text { among students, equal opportunity \& voice, PLUS } \\
\text { share power, apply insights to action options } \\
\text { - Peacemaking Negotiation \&/OR “Deliberation" } \\
\text { (Parker, 2006) \&/or "Praxis" (Freire, 1970) } \\
\text { - Decision check-ins (such as majority-rule voting or } \\
\text { group consensus) may be juxtaposed with episodes of } \\
\text { dialogue. }\end{array}$ \\
\hline
\end{tabular}

This table operationalizes our study's analytical framework, in dialogue with the literature cited earlier. We synthesize the Johnsons' (2009) typology regarding broad goals and climates for conflictual discussion (in particular, competitive debate vs. constructive controversy conversation) with Dull and Murrow's (2008) and Larson and Parker's (1996) typologies regarding the ways teachers may facilitate (teacher-centered vs. open-ended and interpretive) student talk in classrooms. In terms of preparation for constructive conflict talk, explicitly 
teaching constructive conflict norms and skills contributes to both the democratic (equitable agency) and peace-building goals of dialogue (Bickmore, 2013a). Intentional creation of inclusive cooperative environments for conflictual discussion may involve small-group processes such as Johnson and Johnson's Structured Academic Controversy, but also applies to other strategies such as passing a talking piece around a dialogue circle (Pranis, 2005). In observing students' agency and engagement in the conflict talk itself, our classroom observations were sensitive to the possibility that students of different social status, including ethnocultural minority students in relation to majority-group peers, might experience the same dialogue opportunities differently, based on their histories and identities as well as the ways their peers treat them (C. Parker, 2012). Extending the prior scholarship cited in the table (as well as insights arising from our own initial observations), our analytical framework teases out a range of degrees and ways in which students might engage with conflict as a learning opportunity in classrooms.

Given teachers' frequent reluctance to address conflictual issues at all (according to Byford et al., 2009, Hess and Avery 2008, Wilson et al., 2002, and others cited above), the first step in the typology involves opportunities to recognize one's own viewpoint as one among multiple perspectives. Such recognition of the choices implied by conflict creates a space for cognitive and/or imaginative agency, although it offers less opportunity for agency than the more dialogic steps further down the typology. The second step involves communicating one's own perspective, for instance by physically moving to a position in the room signifying a particular opinion. One reason it is important to distinguish this component of democratic peace-building pedagogy is that the literature on factors constraining discussion of conflictual issues (such as Pace 2011 and those just cited) frequently mentions time constraints: unlike sustained discussion, encouraging students to locate themselves in relation to conflicting viewpoints recognizes and creates space for students' agency without requiring much class time. The third step on this continuum finally involves actual dialogue — orally voicing and responding to others' ideas. The pedagogy inviting the highest degree of agency on this continuum adds deliberation (negotiation, praxis, and collective decision-making) to dialogue. Professional development on how to initiate and facilitate constructive conflict discussions may encourage teachers to implement such pedagogies (Bickmore, 2013b).

\section{RESEARCH METHODS}


This research involves qualitative, constructivist analysis of contrasting ways in which dialogue on difficult issues was implemented in four public school contexts, and the implications of such learning opportunities for diverse student participants. It is exploratory, collaborative research, not an evaluation study. Qualitative, comparative case study methods facilitate rich description of complex phenomena, juxtaposing the perspectives of diverse participants with a wider perspective on their social contexts (Miller \& Glassner, 1997). The school and classroom sites were selected purposively to reflect a diversity of approaches, participants, and contexts. The purpose of these teaching case studies is to refine theoretical understandings of how various kinds of dialogic pedagogies, addressing different kinds of conflicts, work in practice in classrooms.

\section{Participants and Data Collection}

Data discussed in this article are drawn from the larger four-year Peace-Building Dialogue in Schools research project, which examined how selected educators implemented constructive dialogue about conflicts and divergent viewpoints in their classrooms, and how to describe and interpret the apparent impact of observed dialogic pedagogies on diverse youth participants, in diverse urban public classroom contexts. The larger project includes (classroom observation and interview-based) case studies of 11 teachers' work in three elementary and four secondary schools, and three teacher professional development initiatives, in one urban school district in southern Ontario, Canada. The professional development initiatives each focused on a different approach to facilitating dialogue about conflict in schools, framed as restorative justice peacemaking or democratic citizenship education (see also Bickmore 2011b, 2013a, 2013b).

In this article, we examine the work of four teachers in two public elementary schools. All of these teachers participated in the same professional development initiative (one of those we studied): a series of workshops that taught a restorative peacemaking circle dialogue process, using a talking piece, designed to facilitate development of community understanding and/or problem-solving to repair damaged relationships. This initiative involved three steps (in separate sessions): preparation and needs assessment, teaching and demonstrating the peacemaking circle in its original use for post-incident problem solving, and then reviewing the circle process and demonstrating how it could be applied to pro-active discussion of conflicts in history and children's literature, to enrich the implemented curriculum as well as to familiarize students with this peacemaking process. This study is not an evaluation of the teachers' practices, nor of the 
professional development initiatives. Rather, our focus is on theory development - improving understanding of the elements of dialogic classroom pedagogies and their implications for building peace and democracy — through carefully-analyzed description of classroom practice.

The four classroom cases examined in this article are located in two small magnet alternative schools within the public system. Each school was explicitly committed to social justice and student-centered learning. While there is certainly ethnocultural, gender, economic class, and other diversity among participants in all of these classrooms, these two schools include somewhat higher proportions of economically comfortable, white, and native English speaking students than the typical population in this school district.

We selected these school sites and classroom teachers for this study based on their clear, enthusiastic commitment to the goals of infusing student-centered conflict dialogue into their implemented curricula. The cases selected for this article constitute two pairs: two primary classrooms in one school and two intermediate classrooms in a similar school. One teacher in each pair emphasized student dialogue about relatively simple disagreements or debates. The other two teachers emphasized engaging students in discussing more complex social identity and justice conflicts. At the same time, there is at least as much overlap as difference among the cases: the pairs are not selected to represent 'better' or 'worse' approaches, but merely to illustrate 'different' approaches to facilitating educative conflict dialogue in classrooms. Three of the four teachers visibly implemented the pedagogical process they were taught in the professional development workshops, using children's fiction to illustrate and engage students in addressing social conflict issues; the other intermediate teacher used a more information-based controversial issues approach. Thus, this article presents and compares four classroom teaching cases, in comparable public alternative schools, in which teachers implemented diverse forms of conflict dialogue pedagogies.

The four case studies presented below are based on: 58 classroom observations (20-60 minutes), classroom materials related to those lessons, and one or two formal 30-60 minute interview(s) with each teacher. Research team members wrote or typed field notes during and immediately after each observation, and audio-recorded teacher interviews, which were subsequently transcribed. The research team consisted of the principal investigator and a fluctuating team of four to seven graduate student assistants who participated at various times during the tenure of this study (2009-2013). While most research assistants were each involved 
only for a few months, the co-authors were the only core members of the research team who participated for the entire life of the project. Data collection was spread over three years, as sets of cases were examined in sequence. One graduate student typically specialized in observations and teacher interviews at each school site, with research team colleagues occasionally involved as co-observers or to observe additional lessons. These overlapping roles contributed to ongoing member checking and continually improved inter-observer reliability in the data collection.

We provided each teacher with their own observation and interview transcripts, inviting feedback and clarification (they requested virtually no changes). Teacher participants included in this article are Nancy Holly (kindergarten) and Fern Brown (grade 1) at Cedar Ridge Primary School, and Tracy Walker (grade 7/8) and Ellen Murphy (grade 7/8) at Watsonville Elementary School (all proper names are pseudonyms). Our research design did not attempt to quantify how often the teachers implemented various conflict dialogue pedagogies in their classrooms. We observed the lessons to which each teacher invited us, based upon their availability and their own beliefs that these lessons related to our research on peacebuilding dialogue pedagogy. This consensual sampling approach resulted in our observing some teachers more than others (see Table 2). We interviewed each teacher twice (35-55 minutes, at their discretion), near the beginning and the end of the period of classroom observation.

\begin{tabular}{|c|c|c|c|c|}
\hline \multicolumn{5}{|c|}{ Table 2. Personal and Professional Context } \\
\hline Name & Grade & School & $\begin{array}{l}\text { Units } \\
\text { observed }\end{array}$ & $\begin{array}{l}\text { Number of } \\
\text { observations }\end{array}$ \\
\hline Nancy Holly & JK/SK & $\begin{array}{l}\text { Cedar Ridge } \\
\text { Primary } \\
\text { School }\end{array}$ & $\begin{array}{l}\text { Language } \\
\text { Arts: social } \\
\text { justice } \\
\text { children's } \\
\text { literature }\end{array}$ & $\begin{array}{l}8(20-40 \\
\text { minutes each })\end{array}$ \\
\hline Fern Brown & Grade 1 & $\begin{array}{l}\text { Cedar Ridge } \\
\text { Primary } \\
\text { School }\end{array}$ & $\begin{array}{l}\text { Language } \\
\text { Arts: social } \\
\text { justice } \\
\text { children's } \\
\text { literature }\end{array}$ & $\begin{array}{l}14(20-40 \\
\text { minutes each) }\end{array}$ \\
\hline Ellen Murphy & Grade $7 / 8$ & $\begin{array}{l}\text { Watsonville } \\
\text { Elementary } \\
\text { School }\end{array}$ & $\begin{array}{l}\text { Social } \\
\text { Studies: } \\
\text { Townhall } \\
\text { Simulation }\end{array}$ & $\begin{array}{l}14(30-45 \\
\text { minutes each) }\end{array}$ \\
\hline Tracy Walker & Grade $7 / 8$ & $\begin{array}{l}\text { Watsonville } \\
\text { Elementary } \\
\text { School }\end{array}$ & $\begin{array}{l}\text { Language } \\
\text { Arts; Social } \\
\text { Studies: The }\end{array}$ & $\begin{array}{l}12,(50-90 \\
\text { minutes each })\end{array}$ \\
\hline
\end{tabular}


Staircase

Unit

\section{Data Analysis}

Our research questions direct us to examine how various kinds and elements of conflictual dialogue (and preparatory activities) were implemented in the case study classrooms, and how diverse students engaged with those opportunities. First, research team members reviewed data immediately after each observation or interview and wrote initial reflective commentaries. At least two team members then coded data line-by-line (Miles \& Huberman, 1994), individually, using a coding guideline based on research literature, pilot study, and initial classroom observations. We then (iteratively) compared and reviewed the coding collaboratively as a research team, discussed similarities and differences, and thereby refined our coding and analytical insights. Following grounded theory guidelines (Charmaz, 2000), we continued to review the data over time, to revisit and refine codes and emergent themes. Each team member wrote analytical summaries of individual cases and groups of cases, and as a research team (and as co-authors) we engaged in many reflective conversations on these initial analyses. To improve analytical strength we revisited both original data and international research literature (Tobin, 1999) to check our emerging understandings of the pedagogical features, implementation issues, and visible consequences for diverse students of various dialogue pedagogies in the selected public classroom settings.

\section{FINDINGS}

\section{Kindergarten and Grade 1: Conflicting Perspectives in Literature Linked to Children's} Lives

We conducted 32 classroom observations (March 2010 to March 2011) of six teachers in a recently-opened alternative (magnet) public school, Cedar Ridge Elementary. All Cedar Ridge teachers had participated in a series of professional development workshops (that we observed, described above) on a restorative dialogue circle process that involved a facilitator (teacher) asking a series of open-ended questions and passing a talking piece. We focus here on Ms. Nancy Holly, the JK/SK teacher (8, 20-40 minute observations) and Ms. Fern Brown, the Grade 1 teacher $(16,25-35$ minute observations), the two who most frequently implemented talking circles and other conflict education in their classrooms. Ms. Holly and Ms. Brown engaged their 
students in circle sharing discussions to develop understanding of characters' viewpoints and social conflict issues in children's literature, in lessons on particular conflict communication norms and skills, and in class meeting circles and teacher-guided conflict resolution discussions to address interpersonal conflicts the children were experiencing among themselves and other classroom community decision making.

\section{Kindergarten: Nancy Holly}

Ms. Nancy Holly’s morning junior and senior Kindergarten class had 11 boys and 4 girls - predominantly white/Anglo and two East Asian students. The alternative public school context offered considerable flexibility, and supported Nancy Holly to incorporate social justice and peacemaking education in her classroom activities. She explained: "Peacemaking is highly accepted in this alternative school. It helps a lot that it's assured that this peacemaking will be carried on in the future, that all the teachers are using it in all the classrooms." In our observations, we found that Ms. Holly consistently took time to prepare her students for dialogue, in particular frequently teaching and engaging her students in practicing the guidelines for taking turns, listening attentively, and responding respectfully to peers in a talking circle. She used a symbolic talking piece that students passed around to give each person a turn to speak, and invited students to remind each other about how they should respect that the person holding the talking piece was the one entitled to speak and (when they were not holding the talking piece) to practice attentive listening.

In most lessons observed, Ms. Holly conducted class meetings or discussion activities in a peacemaking circle format. After the first two in the series of professional development workshops, these often focused on teaching the circle format, how to use a talking piece, listening and speaking skills, while eliciting children's input on questions such as what they liked or would change about their own kindergarten, and about interpersonal relations issues such as social inclusion/exclusion and showing friendship. The following fall, after the third professional development workshop, Ms. Holly began organizing circle dialogue lessons around interpreting and responding to the conflicts and characters' points of view illustrated in children's literature. She combined talking circle guidelines with a "knowledge-building" process learned in other professional development for science education. For instance she described in the 2011 interview a circle in which children "were all sharing different conjectures and viewpoints about why the leaves change colour in the fall. ... They have learned to offer a 
lot of creative, divergent ideas, to listen, and to be respectful of others' ideas."

In one key language arts lesson we observed, Ms. Holly facilitated the children's developing understanding of conflicting viewpoints and invited them to make choices in relation to that conflict (November 25). She invited students to discern the conflicting wants and needs of two characters in a picture book, Hey Little Ant, and eventually to express their own opinions about what they would do if they were the child in the story. Ms. Holly prepared students for this task by asking interpretive questions to uncover each character's interests in a simple but power-imbalanced conflict situation ("What does the boy want?"- to not share his potato chips, and maybe to step on the ant; "What does the ant want?" - to share a potato chip, and to not get squashed). Next, all the children, in pairs, improvised brief skits: one child played the role of the ant, their partner (usually a boy) chose the role of the child. In role, the student pairs had to imagine and represent opposing viewpoints, and to decide: "Should the boy step on the ant or not?" After the role-play, Ms. Holly brought the class together in a circle. First she invited volunteers to summarize the perspectives of each character ("How do you think the ant is feeling?"), then reviewed circle dialogue guidelines. Next, she asked an open question and circulated a talking piece to give each child a chance to go beyond recognizing others' opposing perspectives, to themselves take a perspective (make and express a choice in handling conflict): "If you were the child, what would you do and why?"

Ms. Holly had already taught, and here her students practiced, some constructive conflict communication skills and processes. She introduced a fictional conflict scenario as a learning opportunity, guiding students to interpret and imagine affectively two opposing viewpoints. Further, she delegated to the children the agency to enter into this conflict-first through drama improvisation as characters in the story, then in the dialogue circle articulating and explaining their own preferred decisions in how to address the problem. In the role-play and in the circle, children heard (and occasionally responded to) the contrasting viewpoints of their peers. Ms. Holly's use of a simplified imaginary situation as a conflict case appeared to make it enjoyable and not risky for these young students to participate actively in a conflict dialogue process, in comparison to speaking directly about their own lived experiences. However, in a follow-up interview, Ms. Holly said she was disappointed that some children had acted "silly" in the roleplay, and did not choose non-aggressive alternatives in their responses to the question "what 
would you do." She had facilitated a kind of 'open' dialogue while hoping that students would choose to express values consistent with her own, and not all did so.

Overall, the observations in Ms. Holly's classroom showed that various sharing and dialogue topics influenced students' engagement and participation in different ways. In class meetings - decision-making input such as what children liked and would change in their kindergarten class, or (another day) about their own social exclusion behavior-younger children especially tended to pass the talking piece without speaking or to imitate more confident peers' answers. In simpler discussions based on more distanced (fictional) scenarios such as the one above, every child took an active part in the conflict talk. Ms. Holly circulated a talking piece to encourage all students to articulate and to listen to each other's perspectives. Because passing the talking piece to every child took time, and kindergarteners' attention spans were short, there was little opportunity for students to directly address or challenge each other's perspectives on any particular question. Ms. Holly affirmed in interviews what we consistently observed, that her lessons emphasized preparing students for constructive conflict talk, for instance teaching a three-step conflict management rubric (say what you feel, say what you heard, and say what you need), reviewing guidelines and norms at the beginning of each dialogue circle, and introducing (through stories and sharing) the concept of conflicting perspectives, and occasionally concepts of social difference and unequal power. Her students did exercise some agency in voicing and acting out their viewpoints and experiences, but did not engage in the back-and-forth exchange of fully-developed conflict dialogue. Ms. Holly explained that the professional development workshops on facilitating the circle process had contributed to her sense of confidence and success in working together with her students to discuss and resolve conflicts: "It works well. I'm always there to guide them through it — I ask each person: 'How did you feel? What did you hear [from the conflicting parties participating in this dialogue]? What do you need?" In an interview after the period of observations, Ms. Holly shared her sense that many of her students had absorbed the value of the peacemaking talking circle process, as well as the associated norms and skills, such that they sometimes requested circles and a talking piece for class discussions and to have input in class decision-making.

\section{Grade 1: Fern Brown}

Ms. Fern Brown's grade 1 included 19 students: eight boys and eleven girls, predominantly white/Anglo and almost a third of South Asian and East Asian origin. After the 
first two sessions of Peacemaking Talking Circle professional development, she facilitated students' practice of language similar to what she had already taught them about communicating and listening to engage children in peacemaking circle dialogue. Her students were already familiar with sitting in circles and taking turns speaking. Based on what she had learned in the professional development workshops, Ms. Brown added the component of passing a symbolic talking piece around the circle, and continued refining the sequences of open questions with which she elicited students' contributions.

Like Nancy Holly in kindergarten, Fern Brown often implemented lessons that involved both role play and circle dialogue regarding the divergent points of view (conflicts) in children's literature. More often than Nancy Holly, Fern Brown tended to choose stories that illustrated power-imbalanced conflicts involving human diversity, rights and equity issues, linking these to social studies as well as language arts learning expectations. In each lesson, Fern Brown invited students to interpret each character's wants, needs, and feelings (often using role play to dramatize the contrasting perspectives), to predict consequences of certain action decisions for various parties to the conflicts, and later to tell the class about similar experiences in their own lives. As in Ms. Holly's class, Ms. Brown's students exercised some agency in voicing their viewpoints and experiences (although often giving responses they probably assumed their teacher wanted to hear), but because attention spans were short they did not often engage in direct, back-and-forth peer dialogue.

For example (December 9), Ms. Brown read aloud a story, Amazing Grace, about racismbased social exclusion. Like Ms. Holly, Ms. Brown began with teacher-directed conversation to guide students to distinguish characters' contrasting perspectives, with several students volunteering responses or questions. Ms. Brown then directed students' attention to social diversity and bias, asking them to explain "skin color rudeness" and why it is a problem, "when somebody says you can't do something because of your skin color.” Ms. Brown elicited and affirmed student responses along these lines: "We shouldn't make decisions based on the color of someone's skin." Continuing in an open-structured discussion format (in which only some students volunteered to speak up), Ms. Brown invited children to connect the story's concept of bias-based social exclusion to their personal lives, asking if they had ever been left out of something they wanted to do. She modeled a response to this question by telling her own story about a time when she had been told she was too short to go on an amusement park ride. A boy 
and a girl immediately chimed in: "That happened to me too." This evidently encouraged several other children to risk sharing their own social exclusion experiences with the class: as in the teacher's model, students avoided naming social identity biases, other than being small or young.

At that moment, students took a brief break to move around the room. One boy [White] used his body to prevent a [White] girl from sitting on some blocks in the back of the classroom, sitting in this coveted space himself. Ms. Brown challenged him: "You made up your own rule that [female student] could not sit there." She asked the whole class: "Thinking about the story we just read, what could have been done differently in this situation, to not leave [that classmate] out?" In this instance, Ms. Brown chose to publically confront a student's aggressive response to an interpersonal conflict with a peer. She invited all students in the class to offer alternative choices for addressing this conflict, using the values represented in the literature lesson to support a more equitable and nonviolent resolution. Two or three students, including the boy who had acted aggressively, suggested, "Be nicer and let her sit if there is space."

Using the intersection of the literature lesson with this emergent interpersonal conflict as a learning opportunity, Ms. Brown invited all students to locate themselves in the conflict and to make decisions about how to proceed (not all students volunteered to do so, and those who spoke only advocated what was surely seen as the teacher's "correct" choice). After reading aloud another segment of the story, Ms. Brown explained the difference between unjust exclusion and legitimate disagreement. She concluded: "It is OK to disagree with each other, but we have to find a way to let others like what they want and have their own feelings [when these differ]." While Ms. Brown often circulated a talking piece to give every child a turn, this time she did not. However, most students apparently felt confident enough to volunteer responses at one point or another, speaking to social exclusion in the story and/or their lived experiences.

Another day, students came in from playground recess telling Ms. Brown that [the only boy with African heritage in the class] had pushed a [White] girl down. One girl, saying this was an episode of an on-going problem (boys chasing girls on the playground), suggested that the whole class talk about it in a peacemaking circle. The boy they named moved outside the circle and laid on the floor; Ms. Brown moved to sit beside him. She asked the class why he might be feeling badly and how they could make him feel part of their circle. Later, she asked the girl 
who had been pushed what would make her feel better, and encouraged the boy to apologize to her (he did). Last, she urged him and the whole class to "turn the page for a brand new chance."

Ms. Brown used this episode as an opportunity to teach the idea that the parties to a conflict have different perspectives and feelings, and that everybody makes mistakes and can move on from them. In contrast to the above example (in which a boy had at first denied his aggression), she did not emphasize blame, and facilitated restorative reintegration of a sometimes-aggressive boy into the classroom community. In each episode, Ms. Brown invited the class to examine the viewpoints and beliefs operating in an interpersonal aggression conflict among peers, and to put into words their suggestions for nonviolent resolution - thereby modeling skills and values for constructive conflict communication (the former episode emphasizing non-aggression, the latter emphasizing not holding grudges). The pre-planned lesson (Amazing Grace) explicitly named racism, although most of the follow-up dialogue (when students shared their own experiences) did not. In the second episode, the teacher urged fairness and compassion for a visible minority student, but in neither did the teacher explicitly name students' gender or ethno-racial identity.

On International Women's Day, Ms. Brown read to her class a book, William's Doll, and invited students to compare the main character's toy preference to the children's own recent preferences shared on Toy Day. The character in the story faced gender conformity pressures from his father and grandmother. As Ms. Brown read the story aloud, she stopped at the use of the word "sissy," to make sure her students knew that this was an insult and not "a friendly thing to say." She elaborated in the second interview:

We explored what was William's point of view, what was his grandmother's point of view, what was his father's point of view. And then I asked the kids, what is your point of view. So that was a really good language arts lesson and [later], I integrated it into [a] music [lesson] around gender and sexuality and gender stereotypes.

Ms. Brown was enthusiastic about the value of using peacemaking circles, and discussion of conflicts found in literature, to support students' skills for listening and engaging in constructive and positive communication, and to encourage students to "participate in different ways" in the classroom. Even in the small, cooperative, social justice-oriented environment of Cedar Ridge Elementary, Fern Brown said that it was sometimes difficult to find sufficient, regular time for peacemaking circle dialogue work, amidst academic demands and schedule 
interruptions. She argued that, for the future, the school staff should recognize the academic learning value of circle dialogues_- "It's your oral language, it's your drama ..., it's your emotional work (which isn't on the report card, but) it's your learning skills" — and allocate consistent instructional time for it in the school schedule. She argued, "What you need in order for these peace circles to work, I think, is you need all teachers to be doing them in their classrooms."

The vignettes from these two primary classrooms demonstrate overlapping, but distinct, approaches to implementing dialogue about conflicts in classroom curriculum. Both affirm the findings of previous theory and research that constructive, educative conflict talk in classrooms is entirely possible with very young children (Beck, 2003; Kelly \& Brooks, 2009). Nancy Holly and Fern Brown used the plots and characters of children's literature to illustrate what it meant to hold conflicting perspectives (wants, needs, and feelings), to show that such conflicts presented choices in which participants could respond in different ways to the problems they confronted, and to predict and assess the potential consequences of different conflict management choices (feelings, potential harm, escalation or de-escalation). Both modeled and explicitly taught tangible skills for constructive conflict talk, such as listening and taking turns in speaking (e.g., passing a talking piece). Both delegated to their students responsibility (agency) to autonomously take up conflict talk: both had students role play imagined (characters') perspectives in miniature skits, while Ms. Brown also used conflict resolution concepts from literature and other lessons to challenge the ways her students handled their actual lived disputes with peers. Ms. Brown (grade 1) seemed to more successfully engage her students in discerning and addressing fairness (justice) questions in conflict. Ms. Holly had hoped that her kindergarteners would notice the power imbalance between the child and the ant in the story, and its implicit analogy to bullying problems, but she told us in an interview that she did not feel that this aspect of her lesson had been successful.

By implementing dialogue procedures that explicitly delegated the floor (and the responsibility for discerning and communicating their views) to every student and fostering cooperative environments, teachers engaged a wide range of young students in practicing democratically relevant skills such as listening and voicing viewpoints (peer-to-peer as well as student-to-teacher) in relation to social conflict. Both teachers guided students to imagine, and to voice or enact in role-play, the divergent (emotional as well as intellectual) viewpoints of 
conflicting parties, and to compare these to their own experiences. To some degree, Ms. Holly and especially Ms. Brown introduced questions of bias and justice that are more complex and challenging than simple disputes. That is, they introduced what Hess (2009) calls "settled" as well as "unsettled" conflict issues. While each hoped that their students would adopt human rights-respecting perspectives in relation to the conflicts they discussed, they did not silence students who expressed other perspectives. Both teachers often used fictional literature, roleplay activities, and sharing circles to prepare their students for conflict dialogue by teaching them about the anatomy interpersonal conflicts, social aggression, and sometimes to acknowledge diversity and express dissonant views. Given the students' young ages, it makes sense that these teachers spent a large proportion of their time in preparation- teaching students how to engage in constructive conflict talk-and little time in sustained deliberative decisionmaking dialogue. In these inclusive pedagogies, essentially all their students did practice perspective recognition (conflict analysis) and perspective taking (conflict communication) in relation to scenarios in their own lives, in peers' conflicts they witnessed, and in fictional narratives.

\section{Grade 7 and 8 Cases: Issues Debates or Peacebuilding Dialogue}

We interviewed and conducted 26 classroom observations (March 2010 to April 2011) of two teachers in an established alternative (magnet) public school, Watsonville Elementary School. The two teachers profiled here had participated (with the Cedar Ridge teachers) in the main professional development workshop described above on the restorative dialogue circle process. Ms. Ellen Murphy (14 observations) and Ms. Tracy Walker (12 observations) taught classes of combined grade 7-8 students, in consecutive years, at Watsonville. Although they taught the same official curriculum to comparable students at the same grade level in the same school, Ms. Murphy and Ms. Walker engaged their students in very different kinds of conflict dialogue pedagogies. While Ms. Walker implemented the cooperative dialogue circle methods taught in the professional development workshop and various drama-based pedagogies for encountering conflict, Ms. Murphy implemented a more information-based debating approach to engage her students in addressing controversial issues. Both teachers raised questions of justice and power-imbalanced conflicts for their students' consideration, but in different ways.

\section{Grade 7 and 8 (A): Ellen Murphy}


We conducted 14, 30-40-minute observations of Ms. Ellen Murphy (October 2010 to April 2011), sometimes including her teaching partner Ms. Wood, in a grade 7 and 8 class (sometimes separately, other times in a combined group of 45 students) in an established public alternative school, Watsonville Elementary. Ms. Murphy (not Ms. Wood) had participated in the full-day circle process workshop, but she did not choose to implement any circle dialogue activities. In an interview, Ms. Murphy explained that she didn't believe her students were sufficiently mature, mentioning the large proportion of sometimes-disruptive boys. Ms. Murphy and Ms. Wood did frequently engage their students in discussing social conflict and justice issues in other ways, in particular debating activities and a municipal governance simulation, in several social studies and interdisciplinary units of study.

Interview and observations confirmed that critical thinking and debating skills were main priorities in Ms. Murphy's teaching. For instance, as part of an interdisciplinary unit on hunger, students in small groups negotiated budgets for a "typical" Canadian family household (October 29). In preparation for this exercise, Ms. Murphy led a teacher-directed conversation on distinguishing needs from wants. The grade 8 class was disproportionately male (17 boys and 5 girls, including three South Asian, one East Asian, and White/Anglo students). In this wholeclass discussion, a few boys' voices dominated, while girls' voices were completely absent. More students spoke up in the small group exercise: students researched costs and then debated the relative importance of various entertainment, rent, and food expenses. Ms. Murphy instructed the small groups to reach "consensus," but did not teach them procedural skills or principles about how they might negotiate to achieve such agreement. Ms. Murphy told students to debate, and then if they could not persuade one another, to decide via majority rule vote. As time began to run out near the end of the lesson, the most confident or loudest students generally prevailed, leaving little space for dialogue.

Later in the same unit (November 2), Ms. Murphy's Grade 7 class (14 girls and 10 boys, predominantly White/Anglo with one East Asian and two South Asian students) prepared for a simulated UN World Forum on ending world hunger. The day before, the class had watched a film on exploitative factory farming. Each student was assigned to represent one type of agriculture: subsistence farmers, specialized farmers, or commercial farmers. In small groups containing representatives of each viewpoint, Ms. Murphy told students to: "share expertise and characteristics of each agricultural system; determine their advantages and disadvantages [make 
a chart on poster paper] . . . and decide which system will help to stop world hunger." Ms. Murphy instructed groups to make their decisions via secret-ballot majority vote, but also told them that, "you will have to come to consensus in regard to the [best] agricultural system." Students' conversations referenced information they had looked up in their textbooks, which they knew would be reflected in Ms. Murphy's assessment of their work. Here is one typical exchange observed (names are pseudonyms):

Fred: . . So basically, shade-grown bananas are always better than sun grown bananas. .

.. Shade-grown are individual farmers and sun-grown is bad for the environment because you have to cut down trees.

Jack: I did commercial agriculture.

Lisa: What's that?

Fred: It's awful ... [Referring to the recent film; then, to Jack] If you even argue for your cause, I'll tell you to get out of here now. So, what are we talking about now? Children, cows, pigs?

Jack: I don't even know.

Lisa: I feel so sorry for those pigs and chickens . . .

In the group above, Jack refused to advocate for his assigned perspective (commercial agriculture): it is unclear whether that reluctance reflected his own viewpoint, or the influence of his classmate's threat. Since Ms. Murphy had not taught any particular dialogue principles or skills (or explained "consensus"), students usually defaulted to competitive argument.

The culminating activity of an interdisciplinary unit on water (February 14) was a debate on whether "companies have right to privatize water and charge for its delivery." Ms. Murphy explained the ground rules:

This debate goes in teams.... I am going to choose a viewpoint for you, namely, For (Yes) or Against (No). . . Y Your argument should be backed up by evidence, and you will receive points depending on how strong and convincing your argument is. It is like a televised debate where people talk for a limited amount of time.

Here, students were required to take opposing assigned perspectives on a contentious issue, justifying their arguments with background reading. They presented their positions one at a time (without opportunity for questioning or rebuttal), so peers were not required to listen intensively, 
respond, or negotiate with those holding opposing views. Given the extrinsic incentive of the teacher's assessment, students apparently understood winning this debate in terms of showing the teacher they had done their homework.

A ten-week combined grade 7/8 integrated unit was built around a complex simulation of municipal politics. Ms. Murphy and Ms. Wood assigned each student a role such as mayor, banker, lawyer, sanitation engineer, or car dealer, and placed on their agenda various contentious issues in environmental protection. In role, students formulated policy proposals first in smallgroup "committee" meetings, and then debated and voted on them in periodic whole-class "town hall" meetings, moderated by Ms. Murphy using parliamentary procedure. Again, teachers awarded points to groups and to individual students based on the quality of their verbal arguments.

In contrast to lessons described above that required competitive debate, the small-group committee process provided potential space for students to develop cooperative, inventive dialogue about conflicts, in their preparation for the large group debates. However, partly because Ms. Murphy and Ms. Wood required committees to reach consensus on their proposals in a limited time and did not guide or teach procedural skills for such groupwork, even these small-group conversations sometimes developed as competitive debates. Students generally took up issues only at surface level, many group members were largely silent, and majority rule was assumed.

Overall, Ms. Murphy endeavored to expand students' horizons by engaging them in factfinding and discussion of social conflicts outside their immediate lived experience. Her preference for prepared debate presented multiple opportunities for students to discern and juxtapose opposing viewpoints on potentially contentious issues. Lessons modeled the importance of, and strategies for, articulating perspectives and grounding them in a knowledge base. Students carried out assigned roles or ideological positions, but usually did not voice their own opinions or show that they cared personally about most of these conflicts. The above excerpt from a small-group discussion is an interesting exception, in which the teacher's opinion (represented by the film about the horrors of factory farming) evidently provoked some students both to care and to become intolerant of alternative viewpoints.

These adversarial approaches to conflict talk left little room for dialogue toward mutual understanding. Ms. Murphy did not explicitly guide students in how to engage in mutually 
responsive dialogic exchange, in which they might have listened empathetically or worked to codevelop understanding of each other's point of view. Ms. Murphy's pedagogy focused, overall, on debating toward reaching single (zero-sum) decisions on conflictual problems (with minorities silenced or voted down), rather than on dialogue toward finding multiple potential solutions or consensus (with various powerful and less-powerful stakeholders' viewpoints taken into account).

\section{Grade 7 and 8 (B): Tracy Walker}

During the previous academic year, Ms. Tracy Walker taught the grade 7/8 class at the same school as Ms. Murphy. Ms. Walker also had participated in the circle process professional development workshop. We observed 12 (50-90-minute) sessions of Ms. Walker's language arts and social studies unit (March through June, 2010), in a mixed-grade class that included 11 girls and 15 boys, including one African heritage, four South Asian, three East Asian, and White/Anglo students. Beyond literature study and writing, the integrated unit focused on social bullying in the context of ethno-racial bias. It was organized around a short story, The Staircase by William Bell, that presents multiple stakeholders' perspectives in a complex bias-based social aggression conflict: a Muslim immigrant student in a predominantly White high school, Akmed, has been racially harassed repeatedly, and eventually knocked down a staircase and very seriously hurt. The students in the story have been led to believe that Jason, a popular White student athlete, might have been a main perpetrator in the aggression against Akmed. In addition to the characters in Bell's story, Ms. Walker invented and introduced several additional characters (perspectives on the conflict), including Jason's girlfriend Meghan, her family and friends, and Akmed's family. Ms. Walker taught her students to distinguish, empathize with and critique the perspectives of perpetrators, bystanders, and targets of bias-fueled bullying. She used a variety of pedagogical tools to elicit and prepare students to analyze conflict and to participate in conflict dialogue: role-play, simulations, character sketches, and whole-class discussions. Ms. Walker (with assistance one day from the facilitator of the professional development workshop) also taught her class the peacemaking circle process, and in her culminating activity, students participated in circle dialogue in role as stakeholders in the fictional conflict. 
Drawing on her background in drama, Ms. Walker explicitly taught norms for roleplaying, verbal and non-verbal communication skills for engaging with different viewpoints, and concepts for analyzing social conflict. In one simulation activity early in the unit (March 22), students formed "in-" and "out-" groups based on number cards Ms. Walker handed out at random. To debrief and reinforce concepts of social power and conflict, Ms. Walker invited open whole-class discussion and then individual written journal reflections. In this and other lesson activities, prompts encouraged students to compare the fictional and simulated conflict experiences to their own lived experiences, such as "Who are the jocks in your school?" and "How did it feel to be wanted or not wanted?" Such activities prepared students to examine and discuss personally relevant conflict involving differential power dynamics, in particular social hierarchies and cliques in schools.

A few weeks into the unit, it became evident that the class had generally taken on a negative viewpoint regarding the victim in the story, Akmed. Like the perpetrators in the story, most students seemed to blame Akmed for provoking his peers by being different, expressing his Muslim identity. When Ms. Walker asked students to describe their understanding of Akmed (May 3), 12 students volunteered responses, including:

Hussein (male, racialized minority): He's unpopular.

Nila (female, racialized minority): $\quad$ He's a loner.

Alex (male, White): He's someone that doesn't assimilate.

Kevin (male, racialized minority): He's an outcast.

Angela (female, White): He's Muslim.

Felicia (female, racialized minority): $\quad$ He believes that girls are sluts.

To complicate and challenge students' assumptions, Ms. Walker invented a new story character: Akmed's aunt, Mrs. Souhila. She came into class in role as Aunt Souhila, and was interviewed by the students. When they heard 'Aunt Souhila' describe the extent of Akmed's injuries and the emotional impact of the attack on his family, this evidently provoked many students to rehumanize their perceptions of Akmed. Ms. Walker elicited conflict dialogue by inviting students to respond to her dramatic contestation of their prior perspectives about the victim of aggression, and later (out of role) facilitated an open whole-class debriefing discussion. 
Ms. Walker did not focus her lesson activities on having students discern or assign individual blame for the inter-ethnic violence. Rather, she facilitated discussion of the characters' different points of view, and taught students to differentiate in- from out-groups and wants from needs. For instance, she had two boys dramatize a conflict over a chair (staged, though it appeared real at the time), and elicited students' understandings of each party's wants and needs (May 19). Ms. Walker next invited students to discern their own wants and needs. She then invited students in a large-group open forum to name basic human needs-guiding them to listen, explain, and synthesize ideas until everyone had indicated their agreement on a class list of the five most important human needs: physical and mental protection, recognition and attention, sense of belonging, economic well-being, and control over your life. Thus, like Ms. Murphy in the other grade 7-8 class, Ms. Walker taught the concept of conflicting interests (wants and needs) and engaged students in conflict talk about their own and others' interests. Unlike Ms. Murphy, Ms. Walker also showed her students how to build consensus, through dialogue to deepen understanding and mutual respect for differences.

Ms. Walker guided students to apply their understanding of wants and needs to the story characters. For the unit's culminating activity (June 1, 2 \& 7), Ms. Walker assigned students to roles that represented characters in the story (including the additional invented characters, designed to ensure that perpetrators, victims, and bystanders all had allies included in the dialogue). In the way she constructed and facilitated learning activities, Ms. Walker modeled and engaged students in practicing equitable recognition and representation of diverse stakeholders in conflict talk.

The peacemaking circles (in role) examined social exclusion in three groups sequentially, in 'fishbowl' format with peers observing. A few students acted as co-facilitators of each peacemaking circle role-play. At the beginning of each circle, a student facilitator or Ms. Walker reviewed the guidelines for participating and passing a talking piece, to ensure that all participants would have equitable opportunities to make meaningful contributions to the dialogue. In the role-play, students applied their preparatory learning, interpreting and voicing their characters' feelings and perspectives. In the third peacemaking circle simulation (June 7), Ms. Walker acted as co-facilitator, guiding the dialogue to a deeper level than the previous circles and eliciting examples of bias and social exclusion: 
After introducing herself and the student co-facilitator, Ms. Walker says they have come together to discuss and get to the bottom of what happened to Akmed. She asks students (in role) to talk about a time they had been excluded. She shares her own story first: she had once qualified for a male-only basketball team, but was asked to drop out because there wasn't a female change room. She passes the talking piece to her left. [Names are character roles.]

Teresa [played by a boy]: Jason excluded me because he never invited me to parties. Meghan: In grade 4, I used to wear my hair up, and then I didn't, and I was excluded for that.

Jason: Lately, my friends are not accepting of me; they have excluded me.

Gina: I don't get excluded because I'm popular.

Co-Facilitator [male]: . . . No one wanted me on their team. ...

Akmed's brother Fahid: Someone in my family excluded me. . . .

Akmed's Aunt Souhila [played by a White male]: I didn't get a job because they were racist and I wasn't white. ... .

Circle co-facilitator [Ms. Walker] sums up: We all know what it's like to be excluded. .. . Ms. Walker, in role as a peripherally-involved teenager as well as co-facilitator of the circle dialogue, had prepared students and now modeled how to speak in role about conflict. Students took up the sensitive topic of bias-based social aggression in different ways: Some responded in general terms, apparently reflecting minimal understanding or shallow engagement, while others showed that they identified closely with their roles and that they viscerally understood the problem of bias-based social exclusion. One boy presented having been a target of racism. However, time ran out for the circles before such social conflict issues could be probed or discussed in any depth.

Overall, Ms. Walker's Grade 7/8 unit infused conflict in the implemented curriculum as a dialogic learning opportunity, organized around the examination of a fictitious conflict using dramatic role play, open small-group and whole-class discussions, and peacemaking circles. Ms. Walker guided students to practice dialogue about emotionally vivid social conflict issues, focused on development of nuanced understandings of alternate perspectives taken up both in role and as themselves. 
Like Ms. Murphy in the same grade and school, Ms. Walker assigned her students divergent viewpoint roles that required them to enter into social justice conflict scenarios, in preparation for real conflict dialogue in their lives to come. However, rather than job titles and positions based on non-fiction global citizenship texts, Ms. Walker assigned dramatic roles, involving teenagers not unlike themselves, in an interpersonal conflict drawn from literature. Rather than competitive debate focused on zero-sum decisions and majority rule, Ms. Walker explicitly taught conflict communication norms and skills, and guided students to practice cooperative dialogue to build understanding and just relationships. As in Ms. Holly's Kindergarten class, Ms. Walker's inviting these young adolescents to speak in fictitious roles (rather than as themselves) may have made them feel comfortable to share riskier perspectives on these sensitive issues. Perhaps as a consequence, many of Ms. Walker's students appeared particularly emotionally engaged in the 'conflictuality' of these conflict dialogue activities.

\section{CROSS-CASE DISCUSSION}

To some degree, all of the case study teachers above had transcended the heavy weight of institutional pressures against implementation of dialogic conflict pedagogies in classrooms. The alternative public school environment - including the relatively privileged populations typical in such schools (Cuban, 2001; Metz, 1989), the professional development in conflict dialogue facilitation, and the schools' commitments to social justice and democratic dialogue, likely helped to facilitate these pedagogical innovations. Another feature of both Watsonville's and Cedar-Ridge's alternative school settings was that, unlike typical teachers (Little, 1993), the teachers had opportunities to team-teach and to plan their teaching together. Thus these four case studies illustrate plausible ways school and school district leaders can help to increase students' opportunities to engage in democratic peace-building learning, by demonstrating the ways these public school contexts did support and encourage the teachers' regular implementation of dialogic peace-building pedagogies about conflicts. By their existence, these cases show that such dialogic pedagogies need not be as rare as they are.

Yet, even in these flexible alternative school contexts, neither the primary nor the intermediate teachers facilitated much sustained horizontal (student-student) back-and-forth dialogue, much less deliberation, during our observations. They did prepare the ground and introduce such dialogue by (three of the teachers) teaching norms and skills and by (all four teachers) engaging students in recognizing and expressing divergent and directly-conflicting 
viewpoints. Teacher participants all told us that the pressures of limited time and curriculum coverage mandates, particularly in the intermediate grades context, did impede their implementation of sustained interpretive dialogue about complex conflictual issues. Curriculum mandate pressures were not as noticeable in the primary as in the intermediate classroom contexts, but the short attention spans of young children presented another time-limiting constraint. Although all of the teachers opted to participate in this study because of their commitment to implementing peace-building dialogue about conflicts (and our observations were purposively scheduled on days when the teachers said they planned to lead conflict dialogue pedagogies), we observed little long-term, inclusive exchange or deliberation about heartfelt disagreements. Thus, our study suggests that official curriculum mandates, by demanding coverage of enormous quantities of pre-specified content, may play an important role in impeding implementation of sustained democratic peace-building dialogue pedagogies. With curriculum mandate pressures so intensely felt, even in the relatively privileged and supportive alternative school environments studied here, one may imagine that such pressures might be at least as likely to impede conflict dialogue pedagogies in less privileged environments (as suggested in Kahne \& Middaugh, 2008). Further research is needed to explore this dilemma and potential ways of addressing it.

The alternative school environment clearly did allow for substantial variation in the Watsonville intermediate grades: Ms. Murphy covered a lot of social studies material in a short time, while Ms. Walker in the same context was able to implement (interspersed with other content) a long integrated unit based on one short story. Thus it is interesting that, while both teachers engaged their students frequently in confronting conflict as a learning opportunity, neither found much time for what Dull and Murrow (2008) call sustained interpretive dialogue.

Our study focused on observing and analyzing what teachers implemented in their classrooms practice: their participation in the professional development initiative served primarily as a mechanism to identify and recruit teachers likely to implement different kinds of peace-building dialogue pedagogies. Still, three of these four teachers successfully implemented strategies they learned in the professional development workshops. For instance, Ms. Walker created an entire unit of study about a controversial issue that culminated with students participating in a role-played peacemaking circle, following the process taught in the professional development workshops. Ms. Brown and Ms. Holly also implemented talking 
pieces circle regularly in their Kindergarten and Grade 1 classrooms. Because of the primary children's short attention spans, Ms. Brown's and Ms. Holly's talking circles, as implemented, focused primarily on encouraging students to share their personal perspectives, usually not sustained into dialogue focused on actually probing conflicting viewpoints or resolving a conflictual issue. In contrast to the other three teachers, Ms. Murphy told us in an interview that she did not have the time to implement peacemaking circles in her classroom. Further, like many of the teachers surveyed by Wilson et al., (2002), Ellen Murphy felt that her students were insufficiently mature for constructive participation in the process. Yet, unlike the teachers in that survey, Ellen Murphy did regularly implement conflictual issues discussion in her classroom, although in ways that controlled their participation more (delegated less agency) compared with the other three teachers in this study.

\section{Preparation 'For' Dialogue About Conflict}

Our cases illustrate contrasting ways educators might implement educative conflict dialogue on social conflict issues in classrooms. Primary teachers Ms. Holly and Ms. Brown, and one of the intermediate teachers Ms. Walker, taught 'for' (how to conduct) as well as 'with' conflict dialogue (using the terms of Parker and Hess 2001)_guiding students to notice and develop skills, norms and processes for expressing, listening and responding constructively to conflicting viewpoints. The other intermediate teacher, Ms. Murphy, taught 'with' conflict talk (discussion and debate) without teaching skills or processes 'for' constructive conflict communication. The consistent impression of all observers was that a wider range of students were emotionally and verbally engaged, and peer dominance and exclusion were lower, in the three classrooms that taught 'for' as well as 'with' constructive conflict talk.

The citizenship issues discussion literature cited above emphasizes the importance of building background knowledge and choosing appropriate conflicts for discussion, but other elements of preparation 'for' dialogue are less explicit. Middle school teacher Ms. Walker emphasized preparation for equitable dialogue: inviting into conversations and role play scenarios all major stakeholders, especially where these voices had been absent or demeaned in earlier episodes of the conflict. She gave evident attention to constructing and orienting students to processes, such as talking-piece circles and equal speaking turns, that intentionally redressed power imbalances. Ms. Walker also emphasized individual reflection (to interpret conflicting perspectives and apply them to one's own life), notably by assigning journaling prompts after 
each lesson. With the youngest students, Ms. Holly and Ms. Brown (primary teachers at Cedar Ridge) sometimes directed children to put their heads down for a few seconds, to figure out their own thoughts and feelings, before beginning dialogue. Ms. Walker, Ms. Holly and Ms. Brown also put evident energy into guiding students' development and practice of skills and procedural elements of dialogue (such as how to listen respectfully or to share the floor with a talking piece). In contrast, Ms. Murphy's students often practiced (implicit) competitive habits such as dominating the floor, silencing dissenting views, ignoring evidence, and put-downs. Just as these cases illustrate several approaches to conflict dialogue, they also illustrate several ways of preparing participants, to increase the likelihood that classroom dialogue pedagogies would embody constructive, inclusive, and equitable approaches to conflict.

\section{Entering into Conflicts: Diversity and Divergent Perspectives}

A key element of dialogic conflict education is recognition of alternate perspectives, in particular those perspectives previously marginalized in contexts of injustice. Ms. Brown (grade 1) and Ms. Walker (grade 7-8) taught directly about social difference and unequal power: some students in their classes (but not in the other two teachers' classes) voiced examples or explanations that showed understanding of these complex social conflict elements. Ms. Murphy (grade 7-8) framed subject matter as contentious questions for debate, but placed little emphasis on including previously discounted voices (in the curriculum content or interpersonally in the classroom). Ms. Walker's pair work and talking-piece circle processes elicited substantially different classroom dynamics, bringing a far broader spectrum of student voices and identities into conversations, compared to whole-class open-structured interactions in the same classroom. Thus, conflict education may emphasize teaching and learning substantive subject matter to uncover previously ignored perspectives in the subject matter and in the world, and/or reorganization of pedagogical process to equitably include the diverse viewpoints and identities inside the classroom.

In our observations, two of the teachers explicitly addressed some questions of diversity and equity in relation to the conflicts they studied. Ms. Murphy (grade 7-8) addressed equity questions indirectly in some curriculum content (such as her unit on poverty and hunger), and minimally in pedagogical processes (such as having students work in small groups and requiring each student to speak in some debates), although she did not discuss cultural, ethnic, or racial diversity explicitly in observed lessons. In the same grade and school, Ms. Walker provided 
explicit conceptual scaffolding for addressing cultural, ethnic, or racial diversity/equity, such as the simulation exercise on in- and out-groups, and the selection of a story focused on bias against a Muslim youth. Ms. Holly (kindergarten) addressed the problem of social domination in allegorical terms, using the story about the child who might step on the ant, and implemented pedagogies to invite all students' voices, but did not name social identity differences. Ms. Brown (Grade 1) read stories about — and made value statements against - race- and genderbased bias, although she did not name her students' own identity differences nor elicit much explicit conflict dialogue on such issues. Conflict dialogue pedagogies that are uninformed by marginalized perspectives seem to be considerably less "conscientizing" (Freire, 1970) or "interruptive" of injustice (Davies, 2004) than those that ensure their inclusion.

\section{Entering into Conflicting Perspectives Through Imaginative Role-Plays and Simulations}

All four of these case study teachers invited imaginative (embodied and emotional as well as intellectual) engagement with alternative points of view-by having them play character roles or take ideological positions distinct from their own. When teachers assigned students to voice the perspective of another, this seemed to provide a safe way for diverse students to practice entering into conflicts - allowing them to apply concepts, processes and skills without exposing their own real social vulnerabilities. Here is a fascinating area for future research, to better understand the pedagogical possibilities for helping diverse participants to engage emotionally, imaginatively, and yet safely enough (to be inclusive and non-harmful) in recreating conflict scenarios. We need to know more about whether and how practice with 'safer' conflict talk in classrooms actually does, as intended, 'prepare' learners to be imaginative and inventive (as well as competent, informed and engaged) in addressing the inevitable 'hotter' conflicts in their lives, including the increasingly-polarized interactions that may pass for democratic politics in Western contexts today.

\section{Locating Selves in Disagreement Dialogue: Agency and Collective Decision-Making}

On a foundational level, 'democratic' education aims to help participants develop agency and engagement - a sense of responsibility in 'caring to' engage, a sense of efficacy in 'being able to' engage, and a set of skills and understandings for 'knowing how to' engage in collective disagreement dialogue, problem-solving and decision-making (Bickmore \& Kovalchuk, 2012). A part of this preparation for engaged agency is substantive knowledge-building: knowing what the problems are, knowing alternate and subaltern ways of looking at them, and encountering 
models of active citizens who have cared enough, and found ways, to confront particular social conflicts including injustices. By presenting and eliciting open, constructive confrontation of conflicting viewpoints, all the cases in this research provided some such foundational knowledge-building opportunities. By eliciting and guiding broad student participation in discussing those conflicting viewpoints, each teacher also created some opportunities for development of skill and familiarity with various processes for talking about conflicts. Such implemented curriculum seems to provide some of the prerequisites for agency and engagement.

The other major elements of agency and engagement require sharing power, both reducing the power imbalances among students to create inclusive democratic dialogue spaceswhere those normally silenced or marginalized would have voice and be heard — and teachers delegating authority and sharing responsibility with students - such that students practice 'having' agency and 'having to' engage in discerning and voicing their own viewpoints, grappling with the divergent viewpoints of others, and making collective decisions. To differing extents, each teacher profiled here worked to establish respectful communication norms and multiple, scaffolded ways ‘into’ conflictual conversations (such as individual reflection or small group work prior to large group discussions, and practice with lower-risk and distant conflicts prior to students' own higher-risk conflicts). This seemed to make at least three of these classroom climates fairly safe for constructive, open-minded dialogue that sometimes included lower-status students.

The peacemaking circle process, taught in the professional development sessions provided to these participating teachers, is intrinsically constructed to share power, symbolized by the horizontal open circle structure and by the talking piece that circulates to all participants. While peacemaking circles and other deliberation processes could be used for shared governance, they were not in the cases above. The cases of Ms. Holly, Ms. Brown and Ms. Walker, who used open discussion formats and circles, made evident that a wider range of students voiced views in the circle process compared to the open volunteer formats they also used. Comparison of diverse students' responses to Ms. Walker's open, cooperative dialogue approaches with Ms. Murphy's debate and majority rule approach reinforces Hemmings' (2000) finding that competitive debate approaches tended to narrow the participation of lower-status students compared to open, cooperative approaches. 
In general, it was remarkable how few episodes we found of really passionate, unfettered conflictual conversation about deeply-held concerns, and how few episodes we found of collective decision-making, in any of the above cases, even though we sampled the classroom cases purposively to seek out educators who wanted to (and believed they did) infuse conflictual conversations in their curricula.

\section{CONCLUSION}

The case studies above illustrate contrasting, demonstrably-feasible ways in which teachers in a few urban Canadian public classrooms prepared their students to make sense of, to locate themselves in relation to, and to actually enter into constructive dialogue about social conflict questions. Together, these cases reinforce the findings of prior scholarship that democratic conflict talk can be implemented in public school contexts, at the same time that they highlight the challenges of sustaining sufficient time, flexibility, and professional learning support in school systems constrained by narrow standardized testing, rigid schedules, and limited resources. While this study did not assess student outcomes, our observations of the learning opportunities enacted support the contention in prior scholarship that it is feasible in public classrooms to both prepare participants for, and engage them in, educative dialogue about conflicts, and that these activities can provoke positive, relatively inclusive, citizenship learning opportunities (Applebee et al., 2003; Hahn, 2010; Hess \& Avery, 2008).

Preparation for constructive democratic peace-building dialogue includes teaching students both content knowledge (to overcome ignorance about alternate perspectives) and pedagogical process (showing how to prepare and carry out various approaches to conflictual dialogue). This preparation includes opportunities for developing skills, relationships and interaction norms, guided practice, and debriefing with peers the issues and experienced consequences of those practices.

Some of the topics for conflict dialogue in the case studies involved or implied social diversity and equity questions, and all of the classes included at least some social diversity among participants. Yet we did not find that the conflict dialogue we observed in these classrooms necessarily addressed the diversity elements of these conflicts (or processes) in a concerted, sustained manner that might be expected to interrupt prevailing patterns of inequity. At the same time, patterns observed in our case studies did suggest some key elements that may make such classroom dialogue activities constructive for peacebuilding-including preparation 
and pro-active inclusion of previously-marginalized perspectives - and different ways of facilitating the dialogue itself. Constructive conflict talk is a crucial element of democracy and peace-building that can be taught. There is a great deal more to learn about how best to do so, and how to document the specific consequences for diverse student participants.

Based on the interviews and classroom observations of these four teachers, this research does not contradict previous findings that most teachers do not feel adequately prepared for, or even fear, engaging in controversial issues discussions with their students (e.g., Donnelly \& Hughes, 2006; Torney-Purta, Richardson, \& Barber, 2005; Yamashita, 2006). However, this study also shows that, given both professional development (specific set of strategies and principles for doing so) and supportive school environments, three out of the four observed teachers (Ms. Brown, Ms. Holly \& Ms. Walker) did take the time and the risk to conduct lessons that invited students to discern, articulate, and reflect upon contrasting perspectives, and to practice skills and strategies for peaceful, inclusive, and constructive discussion of such issues.

This study illustrates participating teachers' different approaches and expectations for student talk about conflict — each demonstrating 'ingredients' of dialogue pedagogies relevant to democratic peace-building, although none of them providing an 'ideal' comprehensive model of such pedagogy. The skilled teachers introduced in this article all opted to participate in this study because they believed in, and believed that they themselves used, democratic peacebuilding pedagogies to address conflicts as learning opportunities in their classrooms. Because in this study, as in prior research, we found relatively few opportunities to observe sustained peace-building dialogue pedagogies, we conclude that it is of critical importance to continue working to find feasible ways and spaces to implement sustained dialogic pedagogies that are inclusive of divergent perspectives and marginalized students' voices. The possibilities for improvement of constructive conflict talk practices in diverse public school classrooms are demonstrably attainable.

\section{ACKNOWLEDGEMENTS}

We acknowledge with great appreciation all of the schools, teachers, and students who participated in this study. Members of the research team, each engaged for two months or more from 2009-2013 provided valuable contributions to this research (in alphabetical order): Sardar Anwaruddin; Yomna Awad; Patricia Carbajal; Diane Hamilton; Ahmed Salehin Kaderi; 
Serhiy Kovalchuk; Shannon Larsen; Meg Leitold; Gareth Manning; Brian Moore; Michael Ross; Traci Scheepstra; Julianna Scramstad.

\section{FUNDING}

The Peacebuilding Dialogue in Schools research project gratefully acknowledges funding from the Social Sciences \& Humanities Research Council of Canada (SSHRC).

\section{REFERENCES}

Ahonen, S. (2001). Politics of identity through history curriculum: Narratives of the past for social exclusion - or inclusion? Journal of Curriculum Studies, 33(2), 179-194. doi:10.1080/00220270010011202

Anzaldúa, G. (1987). Borderlands/ La Frontera: The New Mestiza. San Francisco, CA: Spinsters/ Aunt Lute.

Apple, M. (1979). Ideology and Curriculum. London, ON: Routledge.

Applebee, A., Langer, J., Nystrand, M., \& Gamoran, A. (2003). Discussion-based approaches to developing understanding: Classroom instruction and student performance in middle and high school English. American Educational Research Journal, 40(3), 685-730. doi:10.3102/00028312040003685

Arnot, M., \& Dillabough, J. (1999). Feminist politics and democratic values in education. Curriculum Inquiry, 29(2), 159-189. doi:10.1111/0362-6784.00120

Avery, P., Johnson, D., \& Johnson, R. (1999). Teaching an understanding of war and peace through structured academic controversies. In A. Raviv, L. Oppenheimer, \& D. Bar-Tal (Eds.), How children understand war and peace (pp. 260-280). San Francisco, CA: Jossey-Bass.

Avery, P., Sullivan, J., \& Wood, S. (1997). Teaching for tolerance of diverse beliefs. Theory Into Practice, 36(1), 32-38. doi:10.1080/00405849709543742

Barton, K.C. \& McCully, A. (2005). History, identity and the school curriculum in Northern Ireland: An empirical study of secondary students' ideas and perspectives. Journal of Curriculum Studies, 37(1), 85-116. doi:10.1080/0022027032000266070

Barton, K.C., \& McCully, A. (2007). Teaching controversial issues . . where controversial issues really matter. Teaching History, 127, 13-19. Retrieved from http://teachinghistory.org/

Beck, T. (2003). "If he murdered someone, he shouldn't get a lawyer": Engaging young children in civics deliberation. Theory and Research in Social Education, 31(3), 326-346. doi:10.1080/00933104.2003.10473228

Bickmore, K. (2001). Student conflict resolution, power 'sharing' in schools, and citizenship education. Curriculum Inquiry, 31(2), 137-162. doi:10.1111/0362-6784.00189 
Bickmore, K. (2005). Teacher development for conflict participation: Facilitating learning for 'difficult citizenship' education. International Journal of Citizenship and Teacher Education, 1(2). Retrieved from http://www.citized.info

Bickmore, K. (2007). Linking global with local: Cross-cultural conflict education in urban Canadian schools. In F. Leach \& M. Dunne (Eds.), Education, conflict and reconciliation: International perspectives (pp. 237-252). Oxford, UK: Peter Lang.

Bickmore, K. (2008). Social studies for social justice: Learning/ navigating power and conflict. In L. Levstik \& C. Tyson (Eds.), Handbook of research in social studies (pp. 155-171). Mahwah, NJ: Lawrence Erlbaum.

Bickmore, K. (2011a). Education for "peace" in urban Canadian schools: Gender, culture, conflict, and opportunities to learn. In P. P. Trifonas \& B. Wright (Eds.), Critical issues in peace and education (pp. 88-103). New York, NY: Routledge

Bickmore, K. (2011b). Peacebuilding dialogue as democratic education: Conflictual issues, restorative problem-solving, and student diversity in classrooms. In J. Arthur \& H. Cremin (Eds.), Debates in citizenship education (pp. 115-131). New York, NY: Routledge.

Bickmore, K. (2013a). Circle dialogue processes in elementary classrooms: Locations for restorative and educative work. In H. Cremin, E. Sellman, \& G. McCluskey (Eds.) Restorative approaches to conflict in schools. (pp. , 175-191) London: Routledge.

Bickmore, K. (2013b). Incorporating peace-building citizenship dialogue in classroom curricula: Contrasting cases of canadian teacher development. Paper Presented at the meeting of International Congress for School Effectiveness and Improvement, Santiago, Chile (January 3-6).

Bickmore, Kathy \& Kovalchuk, Serhiy (2012). Diverse ways of creating classroom communities for constructive discussions of conflict: Cases from Canadian secondary schools. In P. Cunningham \& N. Fretwell (Editors), Creating communities: Local, national and global. London: CiCe, pp. 590 - 605. Retrieved from www.york.ac.uk/education/research/cresj/citizenship-communities

Bickmore, K., \& MacDonald, A. (2010). Student leadership opportunities for making 'peace' in Canada's urban schools: Contradictions in practice. Interamerican Journal of Education for Democracy/ Revista Interamericana de Educación para la Democracia, 3(2), 126 152. Retrieved from www.ried-ijed.org

Bixby, J., \& Pace, J. (Eds.). (2005). Educating democratic citizens in troubled times. Qualitative Studies of Current Efforts. Albany, NY: SUNY Press.

Boler, M. (1997). The risks of empathy: Interrogating multiculturalism's gaze. Cultural Studies, 11(2), 253-273. doi:10.1080/09502389700490141

Britzman, D. (1992). Decentering discourses in teacher education: Or, the unleashing of unpopular things. In K. Weiler \& C. Mitchell (Eds.), What schools can do: Critical pedagogy and practice (pp. 151-175). Albany: SUNY Press.

Byford, J., Lennon, S., \& Russell, W. B. (2009). Teaching conflictual issues in the social studies: A research study of high school teachers. The Clearing House, 82(4), 165-170. Retrieved from www.jstor.org

Case, R. (1999). Global education: It's largely a matter of perspective. In R. Case \& P. Clark (Eds.), The Canadian anthology of social studies (Vol. 75-83). Vancouver, BC: Pacific Educational Pres. 
Charmaz, K. (2000). Grounded theory: Objectivist and constructivist methods. In N. Denzin \& Y. Lincoln (Eds.), Handbook of Qualitative Research (2nd ed., pp. 509-535). Thousand Oaks, CA: Sage Publications.

Claassen, R. \& Claassen, R. (2004, Winter). Creating a restorative discipline system: Restorative justice in schools. The Fourth $R, 9-12$. Retrieved from http://www.mediate.com/acreducation/pg7.cfm

Claire, H, \& Holden, C. (Eds.). (2007). The challenge of teaching controversial issues. London, UK: Trentham Books.

Cohen, E. (1994). Designing groupwork (2 $2^{\text {nd }}$ edition). New York: Teachers College Press.

Cohen, E. (2004). Producing equal-status interaction amidst classroom diversity. In W. Stephan \& W.P. Vogt (Eds.), Education programs for improving intergroup relations (pp. 37-54). New York: Teachers College Press.

Crocco, M. S. \& Cramer, J. (2005). Women, WebQuests, and controversial issues in the social studies. Social Education, 69(3), 143-148. Retrieved from http://www.socialstudies.org/

Cuban, L. (2001). How systemic reform harms urban schools. Retrieved May 30, 2001, from http://www.edweek.org

Curle, A., Freire, P., \& Galtung, J. (1974). What can education contribute towards peace and social justice? Curle, Freire, Galtung panel. In M. Haavelsrud (Ed.), Education for Peace: Reflection and Action (pp. 64 - 97). Keele, UK: University of Keele.

Davies, L. (2004). Education and conflict: Complexity and chaos. London: Routledge/Falmer.

Davies, L. (2005). Teaching about conflict through citizenship education. International Journal of Citizenship and Teacher Education, 1(2), 17-34. Retrieved from http://www.citized.info/

Day, L. (2002). Putting yourself in other people's shoes: the use of Forum theatre to explore refugee and homeless issues in schools. Journal of Moral Education, 31(1), 21-34. doi:10.1080/03057240120111418

Dean, B. \& Joldoshalieva, R. (2007). Key strategies for teachers new to conflictual issues. In H. Claire \& C. Holden (Eds.), The Challenge of Teaching Conflictual Issues. London, UK: Trentham Books.

Dei, G. S. (2000). Towards an anti-racism discursive framework. In G. S. Dei \& A. Calliste (Eds.), Power, Knowledge, and Anti-racism Education. Halifax, NS: Fernwood.

DeNicolo, C. P. \& Franquiz, M. E. (2006). 'Do I have to say it?' Critical encounters with multicultural children's literature. Language Arts, 84(2), 157-170. Retrieved from http://www.jstor.org/

Donnelly, C. \& Hughes, J. (2006). Contact, culture and context: Evidence from mixed faith schools in Northern Ireland and Israel. Comparative Education 42(4), 493-516.

Dull, L. \& Murrow, S. (2008). Is dialogic questioning possible in social studies classrooms? Theory and Research in Social Education, 36(4), 391-412.

doi:10.1080/00933104.2008.10473381

Epstein, T. (2000). Adolescents' perspectives on racial diversity in U.S. history: Case studies from an urban classroom. American Educational Research Journal, 37(1), 185-214. doi:10.2307/1163476

Espinosa, L. (2003). Seventh graders and sexism: A new teacher helps her students analyze gener stereotypes in the media. Rethinking Schools, 17(3), 17-19. Retrieved from http://www.rethinkingschools.org/ 
Fain, J. G. (2008). 'Um, they weren't thinking about their thinking:' Children's talk about issues of oppression. Multicultural Perspectives, 10(4), 201-208. doi:10.1080/15210960802526102

Fine, M. (1993). 'You can't just say that the only ones who can speak are those who agree with your position:' Political discourse in the classroom. Harvard Educational Review, 63(4), 412-433.

Finley, L. (2003). How can I teach peace when the book only covers war? Online Journal of Peace and Conflict Resolution, 5(1), 150-165. Retrieved from http://ojpcr.org/

Finn, P. (1999). Literacy with an attitude: Educating working-class children in their own selfinterest. Albany, NY: SUNY Press.

Frankenstein, M. (1987). Critical mathematics education: An application of Paulo Freire's epistemology. In I. Shor (Ed.), Freire for the classroom: A sourcebook for liberatory teaching (pp. 180-210). Portsmouth, NH: Boynton-Cook.

Freire, P. (1970). Pedagogy of the oppressed. New York: Seabury Press.

Freire, P. (1998). Pedagogy of freedom: Ethics, democracy, and civic courage. Lanham, MD: Rowman \& Littlefield.

Funk, N., \& Said, A. A. (2004). Islam and the West: Narratives of conflict and conflict transformation. International Journal of Peace Studies, 9(1), 1-28. Retrieved from www.gmu.edu/

Gordon, T., Holland, J., \& Lahelma, E. (2000). Making spaces: Citizenship and difference in schools. London, UK: MacMillan.

Hahn, C. (1998). Becoming Political: Comparative Perspectives on Citizenship Education. Albany, NY: State University of New York Press.

Hahn, C. (2010). Comparative civic education research: What we know and what we need to know. Citizenship Teaching and Learning, 6(1), 5-23. doi:10.1386/ctl.6.1.5_1

Harris, I. (2004). Peace education theory. Journal of Peace Education, 1(1), 5-20. doi:10.1080/1740020032000178276

Hemmings, A. (2000). High school democratic dialogues: Possibilities for praxis. American Educational Research Journal, 37(1), 67-91. doi:10.3102/00028312037001067

Hess, D. (2009). Controversy in the Classroom: The Democratic Power of Discussion. New York: Routledge.

Hess, D., \& Avery, P. (2008). Discussion of controversial issues as a form and goal of democratic education. In J. Arthur, I. Davies \& C. Hahn (Eds.), The Sage handbook of education for citizenship and democracy (pp. 506-518). Los Angeles and London: Sage Publications.

Hollingworth, L. (2009). Complicated conversations: Exploring race and ideology in an elementary classroom. Urban Education, 44(1), 30-58. doi:10.1177/0042085907312496

Houser, N. (1996). Negotiating dissonance and safety for the common good: Social education in the elementary classroom. Theory and Research in Social Education, 24(3), 294-312. doi:10.1080/00933104.1996.10505780

Howard, T. (2004). Does race really matter? Secondary students' construction of racial dialogue in the social studies. Theory and Research in Social Education, 32(4), 484-502. doi:10.1080/00933104.2004.10473266

Hughes, A., Print, M., \& Sears, A. (2010). Curriculum capacity and citizenship education: A comparative analysis of four democracies. Compare: A Journal of Comparative and International Education, 40(3), 293-309. doi:10.1080/03057920903395528 
Johnson, D., \& Johnson, R. (2009). Energizing learning: The instructional power of conflict. Educational Researcher, 38(1), 37-51. doi:10.3102/0013189X08330540

Jones, T. (2004). Conflict resolution education: The field, the findings, and the future. Conflict Resolution Quarterly, 22(1-2), 233-267. doi:10.1002/crq.100

Kahne, J., \& Middaugh, E. (2008, February). Democracy for some: The Civic opportunity gap in high school. Retrieved July 20, 2010, from http://www.civicyouth.org/

Kahne, J., \& Sporte, S. (2008). Developing citizens: The impact of civic learning opportunities on students' commitment to civic participation. American Educational Research Journal, 45(3), 738-766. doi:10.3102/0002831208316951

Kelly, D., \& Brooks, M. (2009). How young is too young? Exploring beginning teachers' assumptions about young children and teaching for social justice. Equity and Excellence in Education, 42(2), 202-216. doi:10.1080/10665680902739683

King, J. (2009). Teaching and learning about controversial issues: Lessons from Northern Ireland. Theory and Research in Social Education, 37(2), 215-246. doi:10.1080/00933104.2009.10473395

Kohlmeier, J. (2006). 'Couldn't she just leave?' The relationship between consistently using class discussions and the development of historical empathy in a 9th grade world history course. Theory and Research in Social Education, 34(1), 34-57. doi:10.1080/00933104.2006.10473297

Kumashiro, K. (2000). Toward a theory of anti-oppressive education. Review of Educational Research, 70(1), 25-53. doi:10.3102/00346543070001025

Ladson-Billings, G. (1995). Toward a theory of culturally relevant pedagogy. American Educational Research Journal, 35, 465-491. doi:10.3102/00028312032003465

Larson, B., \& Parker, W. (1996). What is classroom discussion? A look at teachers' conceptions. Journal of Curriculum and Supervision, 11(2), 110-126. Retrieved from http://www.ascd.org/

Little, J. W. (1993). Teachers' professional development in a climate of educational reform. Educational Evaluation and Policy Analysis, 15(2), 129-151. doi:10.2307/1164418

Luke, A. (2000). Critical literacy in Australia: A matter of context and standpoint. Journal of Adult and Adolescent Literacy, 43(5), 448-461. Retrieved from http://www.jstor.org/

Mátrai, Z. (2002). National identity conflicts and civic education: A comparison of five countries. In G. Steiner-Khamsi, J. Torney-Purta \& J. Schwille (Eds.), New Paradigms and Recurring Paradoxes in Education for Citizenship: An International Comparison (pp. 85-104). Amsterdam: JAI/ Elsevier Science.

McCall, A. (2004). Using poetry in social studies classes to teach about cultural diversity and social justice. The Social Studies, 95(4), 172-176. doi:10.3200/TSSS.95.4.172-176

McKenzie, M. (2006). Three portraits of resistance: The (un)making of Canadian students. Canadian Journal of Education, 29(1), 199-222. doi:10.2307/20054153

McLaughlin, M., Pfeifer, R., Swanson-Owens, D., \& Yee, S. (1986). Why teachers won't teach. Phi Delta Kappan, 67(6), 420-426. Retrieved from http://www.jstor.org/

Metz, M. H. (1989). Real school: A universal drama amid disparate experience. In D. Mitchell \& M. Goertz (Eds.), Education Politics for the New Century: The 20th Anniversary Handbook of the Politics of Education Association (pp. 75-91). London: Falmer Press.

Miles, M. B., \& Huberman, A.M. (1994). Qualitative data analysis: An expanded sourcebook (2nd ed.). Thousand Oaks, CA: Sage. 
Miller, J., \& Glassner, B. (1997). The 'inside' and the 'outside:' Finding realities in interviews. In D. Silverman (Ed.), Qualitative research: Theory, method and practice (pp. 99-112). Thousand Oaks, CA: Sage.

Morrison, B. (2007). Restoring safe school communities: a whole school response to bullying, violence and alienation. Leichhardt, New South Wales, Australia: Federation Press.

Murphy, K. (2010). Teaching a Holocaust case study in a post-conflict environment: Education as part of violence, reconstruction and repair. Intercultural Education, 21(1), 71-77. doi:10.1080/14675981003737208

Obenchain, K. M., Pennington, J. L., \& Orr, A. (2010). Angela: On a critical curve. Theory and Research in Social Education, 38(4), 486-514. doi: 10.1080/00933104.2010.10473437

O'Toole, J., \& Burton, B. (2005). Acting against conflict and bullying. The Brisbane DRACON project 1996-2004 - emergent findings and outcomes. Research in Drama Education, 10(3), 269-283. doi:10.1080/13569780500275873

Pace, J. (Ed.). (2005). Classroom authority: Theory, research and practice. Mahwah, NJ: Lawrence Earlbaum Associates.

Pace, J. (2011). The complex and unequal impact of high stakes accountability on untested social studies. Theory and Research in Social Education, 39(1), 32-60. doi:10.1080/00933104.2011.10473446

Parker, C. A. (2012). Inclusion in peacebuilding education: Discussion of diversity and conflict as learning opportunities for immigrant students. (Unpublished doctoral dissertation). University of Toronto, Toronto.

Parker, C., \& Bickmore, K. (2012). Conflict management and dialogue with diverse immigrant students: Novice teachers' approaches and concerns. Journal of Teaching and Learning, 8(2), 47-64.Retrieved from http://ojs.uwindsor.ca/

Parker, W. C. (2003). Teaching democracy: Unity and diversity in public life. New York: Teachers College Press.

Parker, W. C. (2006). Public discourses in schools: Purposes, problems, possibilities. Educational Researcher, 35(8), 11-18. doi:10.3102/0013189X035008011

Parker, W. C. (2010). Listening to strangers: Discussion in democratic education. Teachers College Record, 112(11), 2815-2832. Retrieved from www.tcrecord.org/

Parker, W. C., \& Hess, D. (2001). Teaching with and for discussion. Teaching and Teacher Education, 17 (3), 273-289. doi:10.1016/S0742-051X(00)00057-3

Pranis, K. (2005). The little book of circle processes: A new/old approach to peacemaking. Intercourse, PA: Good Books.

Pranis, K., Stuart, B., \& Wedge, M. (2003). Peacemaking circles: From crime to community. St. Paul, MN: Living Justice Press.

Prutzman, P., \& Johnson, J. (1997). Bias awareness and multiple perspectives: Essential aspects of conflict resolution. Theory Into Practice, 36(1), 26-31. doi:10.1080/00405849709543741

Ross, M. H. (2007). Cultural contestation in ethnic conflict. New York: Cambridge University Press.

Schirch, L., \& Campt, D. (2007). The little book of dialogue for difficult subjects. Intercourse, PA: Good Books, Inc.

Schultz, K. (2009). Rethinking classroom participation: Listening to silent voices. New York: Teachers College Press. 
Schulz, W., Ainley, J., Fraillon, J., Kerr, D., \& Losito, B. (2009). Civic knowledge, attitudes, and engagement among lower-secondary school students in 38 countries. International Civics and Citizenship Study 2009 international report. Retrieved February, 2011, from http://www.iea.nl/iea_publications.html

Schweber, S. (2006). 'Breaking down barriers' or 'building strong Christians:' Two treatments of Holocaust history. Theory and Research in Social Education, 34(1), 41-50. doi:10.1080/00933104.2006.10473296

Sears, A., \& Hughes, A. (2006). Citizenship: Education or indoctrination. Citizenship Teaching and Learning, 2(1), 3-17. Retrieved from www.citized.info/

Settlage, J., \& Sabik, C. M. (1996). Harnessing the positive energy of conflict in science teaching. Theory Into Practice, 36(1), 39-45. doi:10.1080/00405849709543743

Sills-Briegel, T., \& Camp, D. (2000). Using literature to explore social issues. The Social Studies, 92(2), 65-68. doi:10.1080/00377990009602453

Simon, K. (2001). Moral questions in the classroom. New Haven: Yale University Press.

Skiba, R. (2000). Violence prevention and conflict resolution curricula: What works in preventing school violence. Bloomington, IN: Indiana University.

Smith, S., \& Fairman, D. (2005). The integration of conflict resolution into the high school curriculum: The example of workable peace. In N. Noddings (Ed.), Educating Citizens for Global Awareness (pp. 40-56). New York: Teachers College Press.

Stevahn, L. (2004). Integrating conflict resolution training into the curriculum. Theory Into Practice, 43(1), 50-58. doi:10.1207/s15430421tip4301_7

Subedi, B. (2008). Fostering critical dialogue across cultural differences: A study of immigrant teachers' interventions in diverse schools. Theory and Research in Social Education, 35(4), 413-440. doi:10.1080/00933104.2008.10473382

Tawil, S., \& Harley, A (Eds.). (2004). Education, conflict, and social cohesion. Geneva: UNESCO/ International Bureau of Education.

Tobin, J. (1999). Method and meaning in comparative classroom ethnography. In R. Alexander (Ed.), Learning from Comparing (pp. 113-134). Oxford, UK: Symposium Books.

Torney-Purta, J., Lehmann, R., Oswald, H., \& Schultz, W. (2001). Citizenship and education in twenty-eight countries: Civic knowledge and engagement at age fourteen. Amsterdam: IEA (International Assn. for the Evaluation of Educational Achievement).

Torney-Purta, J., Richardson, W. K., \& Barber, C. H. (2005). Teachers' educational experience and confidence in relation to students' civic knowledge across countries. International Journal of Citizenship and Teacher Education, 1(1), 32-57. Retrieved from www.citized.info/

Wasson, R., Anderson, R., \& Suriani, M. (1999). Integrating a multicultural peacebuilding strategy into a literacy curriculum. In L. Forcey \& I. Harris (Eds.), Peacebuilding for adolescents (pp. 119-138). New York, NY: Peter Lang.

Williams, J. (2004). Civil conflict, education, and the work of schools: Twelve propositions. Conflict Resolution Quarterly, 21(4), 471-481. doi:10.1002/crq.75

Wilson, E., Haas, M., Laughlin, M., \& Sunal, C. (2002). Teachers' perspectives on incorporating current controversial issues into the social studies curriculum. International Social Studies Forum, 2(1), 31-45. Retrieved from http://www.infoagepub.com/

Yamashita, H. (2006). Global citizenship education and war: The needs of teachers and learners. Educational Review, 58(1), 27-39. doi:10.1080/00131910500352531 
Zembylas, M., Bekerman, Z., McGlynn, C., \& Ferreira, A. (2009). Teachers' understanding of reconciliation and inclusion in mixed schools of four troubled societies. Research in Comparative and International Education, 4(4), 406-422. doi:10.2304/rcie.2009.4.4.406

\section{ABOUT THE AUTHORS}

KATHY BICKMORE is a Professor in the Department of Curriculum, Teaching, and Learning at the Ontario Institute for Studies in Education, University of Toronto, Toronto, ON, Canada. She can be contacted at k.bickmore@utoronto.ca.

CHRISTINA PARKER is an Instructor in the Faculty of Community Services at Ryerson University, Toronto, ON, Canada. She can be contacted at christina.parker@ryerson.ca. 